Original article

\title{
Conformational restriction of aryl thiosemicarbazones produces potent and selective anti-Trypanosoma cruzi compounds which induce apoptotic parasite death
}

\author{
Diogo Rodrigo Magalhaes Moreira ${ }^{\mathrm{a}, *}$, Ana Daura Travassos de Oliveira ${ }^{\mathrm{b}}$, \\ Paulo André Teixeira de Moraes Gomes ${ }^{b}$, Carlos Alberto de Simone ${ }^{c}$, Filipe Silva Villela ${ }^{d}$, \\ Rafaela Salgado Ferreira ${ }^{d}$, Aline Caroline da Silva ${ }^{e}$, Thiago André Ramos dos Santos ${ }^{e}$, \\ Maria Carolina Accioly Brelaz de Castro ${ }^{\mathrm{e}}$, Valéria Rego Alves Pereira ${ }^{\mathrm{e}}$, \\ Ana Cristina Lima Leite ${ }^{\mathrm{b}, *}$ \\ ${ }^{a}$ Fundação Oswaldo Cruz, Centro de Pesquisas Gonçalo Moniz, CEP 40296-710 Salvador, BA, Brazil \\ ${ }^{\mathrm{b}}$ Universidade Federal de Pernambuco, Departamento de Ciências Farmacêticas, CEP 50740-520 Recife, PE, Brazil \\ ${ }^{\mathrm{c}}$ Universidade de São Paulo, Instituto de Física de São Carlos, CEP 13560-970 São Carlos, SP, Brazil \\ ${ }^{\mathrm{d}}$ Universidade Federal de Minas Gerais, Departamento de Bioquímica e Imunologia, CEP 31270-901 Belo Horizonte, MG, Brazil \\ e Fundação Oswaldo Cruz, Centro de Pesquisas Aggeu Magalhães, CEP 50670-420 Recife, PE, Brazil
}

\section{A R T I C L E I N F O}

\section{Article history:}

Received 18 November 2013

Received in revised form 30 January 2014

Accepted 2 February 2014

Available online 3 February 2014

\section{Keywords:}

Chagas disease

Trypanosoma cruzi

Thiosemicarbazones

Hydrazones

Conformational restriction

Apoptosis

\begin{abstract}
A B S T R A C T
Chagas disease, caused by Trypanosoma cruzi, is a life-threatening infection leading to approximately 12,000 deaths per year. T. cruzi is susceptible to thiosemicarbazones, making this class of compounds appealing for drug development. Previously, the homologation of aryl thiosemicarbazones resulted in an increase in anti-T. cruzi activity in comparison to aryl thiosemicarbazones without a spacer group. Here, we report the structural planning, synthesis and anti-T. cruzi evaluation of new aryl thiosemicarbazones $(\mathbf{9 a}-\mathbf{x})$, designed as more conformationally restricted compounds. By varying substituents attached to the phenyl ring, substituents were observed to retain, enhance or greatly increase the anti-T. cruzi activity, in comparison to the nonsubstituted derivative. In most cases, hydrophobic and bulky substituents, such as bromo, biphenyl and phenoxyl groups, greatly increased antiparasitic activity. Specifically, thiosemicarbazones were identified that inhibit the epimastigote proliferation and were toxic for trypomastigotes without affecting mouse splenocytes viability. The most potent anti-T. cruzi thiosemicarbazones were evaluated against cruzain. However, inhibition of this enzyme was not observed, suggesting that the compounds work through another mechanism. In addition, examination of $T$. cruzi cell death showed that these thiosemicarbazones induce apoptosis. In conclusion, the structural design executed within the series of aryl thiosemicarbazones $(\mathbf{9 a}-\mathbf{x})$ led to the identification of new potent antiT. cruzi agents, such as compounds $(\mathbf{9 h})$ and $(\mathbf{9 r})$, which greatly inhibited epimastigote proliferation, and demonstrated a toxicity for trypomastigotes, but not for splenocytes. Mechanistically, these compounds do not inhibit the cruzain, but induce T. cruzi cell death by an apoptotic process.
\end{abstract}

(C) 2014 Elsevier Masson SAS. All rights reserved.

\section{Introduction}

Chagas disease, caused by the flagellate protozoan Trypanosoma cruzi, affects approximately 10 million people in Latin America [1]. Currently, the only drug in use is nitroheterocyclic benznidazole (LAFEPE, Brazil), which is effective in curing the disease in the acute

\footnotetext{
* Corresponding authors.

E-mail addresses: diogollucio@gmail.com, diogollucio@yahoo.com.br (D.R. Magalhaes Moreira), ana.leite@pq.cnpq.br (A.C.L. Leite).
}

phase, but is less effective in patients that progressed to the chronic phase [2,3]. Furthermore, benznidazole is less than ideal due to the fact that it causes severe side effects, leading to treatment interruption in a large number of patients [4]. In fact, Chagas disease is considered to be 'the most concerning' infectious tropical disease in Latin America [5]. Thus, there is a need to identify new pharmaceuticals for its treatment.

To address this need, a number of molecular targets for antiT. cruzi drugs have been investigated, increasing the quality of drug identification for Chagas disease treatment. Examples of such 
<smiles>NC(=S)N/N=C/CCc1ccccc1</smiles><smiles>Cc1ccc(SC/C=N/N=C2\NC(=O)C(C)S2)cc1</smiles><smiles>NC(=S)N/N=C/CSc1ccccc1</smiles><smiles>C/C(COc1ccccc1)=N\N=C1/SC(C(C)C)C(=O)N1c1ccccc1</smiles>

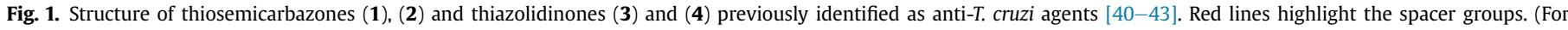
interpretation of the references to color in this figure legend, the reader is referred to the web version of this article.)

targets are the lanosterol $14 \alpha$-demethylase [6], trypanothione reductase [7], cruzain [8], trans-sialidase [9] and phosphatidylinositol 3-kinase [10]. By using structure-based drug design, two small-molecules were recently developed and are now considered strong drug candidates: K11777, a vinyl sulfone peptide that inhibits cruzain [11], and VNI, an oxadiazole derivative inhibitor of $14-\alpha$-demethylase activity $[12,13]$. These compounds are likely to enter into clinical trials; however, the chances of any drug being approved in the clinical stage are very low. Additionally, with the goal of avoiding the development of resistant $T$. cruzi strains, there is a necessity for combined drug therapy $[14,15]$. Therefore, the number of potential drug candidates must be enhanced. Given the outcomes observed for K11777 and VNI as anti-T. cruzi agents, the design of compounds to inhibit cruzain and the 14- $\alpha$-demethylase activity have received special attention $[16,17]$.

Cruzain, the major trypanosomal cysteine protease, is involved during the parasite invasion, differentiation and proliferation in host cells [18]. Specifically, it is responsible for degrading host cell proteins, and therefore contributing to the outcome of the infection [19]. Regarding the identification of cruzain inhibitors, most of the efforts have been conducted through the investigation of peptides and peptide-like compounds, such as ureas [20,21], hydrazones [22-25], triazoles [26,27] and thiosemicarbazones [28-30]. Thiosemicarbazones were originally developed as potential cathepsin- $\mathrm{L}$ inhibitors, one of the principal proteases involved in cancer cells [28]. However, based on the homology and similar biochemical properties between cathepsin-L and cruzain, thiosemicarbazones were investigated as a potential class of cruzain inhibitors. Later on, aryl thiosemicarbazones were found to be a class of anti-T. cruzi compounds that inhibits cruzain activity $[29,30]$.

The general binding mode for aryl thiosemicarbazones with cruzain involves covalent binding of a thioamide group to Cys25 amino acid, as well as location of the aryl group within a deep hydrophobic pocket [30,31]. Based on this model, a number of molecular modifications have been investigated, including bis-thiosemicarbazones, heterocyclic-derived thiosemicarbazones, thiosemicarbazones containing bioreductive groups and metallic complexes [32-37]. This model suggests that aryl thiosemicarbazones contain two different structural determinants and therefore the presence of a spacer group (i.e., the homologation strategy) $[38,39]$ between the aryl group and thiosemicarbazone is a feasible plan to enhance potency of the anti-T. cruzi and cruzain activity.

Our group has observed that the use of homologation strategy produces thiosemicarbazones with enhanced anti-T. cruzi activity in comparison to thiosemicarbazones without a spacer group. Thiosemicarbazones (1) and (2) exhibited higher anti-T. cruzi activity when compared to their respected analogs lacking a spacer group $[40,41]$. As limitation, these compounds displayed lower antiparasitic activity as well low selectivity indexes than benznidazole. The same strategy was employed in thiosemicarbazone bioisosters, leading to the identification of potent anti-T. cruzi thiazolidinones, exemplified by compounds (3) and (4) (Fig. 1) $[42,43]$.

Recent studies have demonstrated examples of the homologation strategy for drug design by using spacer groups with some degree of conformational restriction (i.e., high rotational energy barrier) [44-48]. The preparation of more conformationally restricted $\mathrm{N}$-acylhydrazones, as well as thiosemicarbazones, has produced compounds with enhanced antiparasitic activity $[49,50]$. Based on these findings, we hypothesized that applying this strategy would increase the anti-T. cruzi activity for the compound (1) chemical class. Therefore, we selected the alkoxyl group displayed in Fig. 2 as the spacer group for aryl thiosemicarbazone homologation, which would increase molecular rigidity, as well as rapidly enable synthesis of multiple derivatives.

Here, we used the alkoxyl spacer group to prepare a new series of aryl thiosemicarbazones $(\mathbf{9} \mathbf{a}-\mathbf{x})$ (Fig. 2). A range of substituents were attached to the phenyl ring to examine their role in terms of electronic and steric contribution to the anti-T. cruzi activity. First, we prepared 4-substituted phenyl derivatives, followed by preparation of derivatives with one substituent at position 3- or 2- in the phenyl ring. Derivatives containing two substituents attached to the phenyl ring were synthesized, as well as the replacement of a phenyl by a naphthyl ring. The substituents were selected based on the Hammett Rho values as well as the hydrophobic parameter Pi, therefore, enabling to examine the substituent effect for the aryl reactivity. Evaluation of the anti-T. cruzi and cruzain activity for the compounds $(\mathbf{9 a}-\mathbf{x})$ led to the identification of a number of structure-activity relationships, which ultimately resulted to the identification of new compounds equally or more potent than benznidazole.

\section{Results}

\subsection{Synthesis}

The synthetic procedures employed in aryl thiosemicarbazones $(\mathbf{9 a}-\mathbf{x})$ preparation is shown in Scheme 1. First, the phenolic compounds ( $\mathbf{5} \mathbf{a}-\mathbf{x}$ ) reacted with 3 -chloro-2-butanone $(\mathbf{6})$ in basic conditions at room temperature, similar to previously described protocol [51]. After $12 \mathrm{~h}$ of reaction, $\beta$-ketoether $(\mathbf{7 a}-\mathbf{x})$ compounds were obtained with yields varying from 66 to $99 \%$. Compounds $(\mathbf{7 a}-\mathbf{x})$ were then reacted with thiosemicarbazide (8) and catalytic $\mathrm{HCl}$ in an ultrasound bath at room temperature [52]. After $2 \mathrm{~h}$, thiosemicarbazones $(\mathbf{9 a}-\mathbf{x})$ precipitated in the reaction mixture, which were collected by simple filtration. All thiosemicarbazones $(\mathbf{9 a}-\mathbf{x})$ were recrystallized and obtained at an acceptable purity 

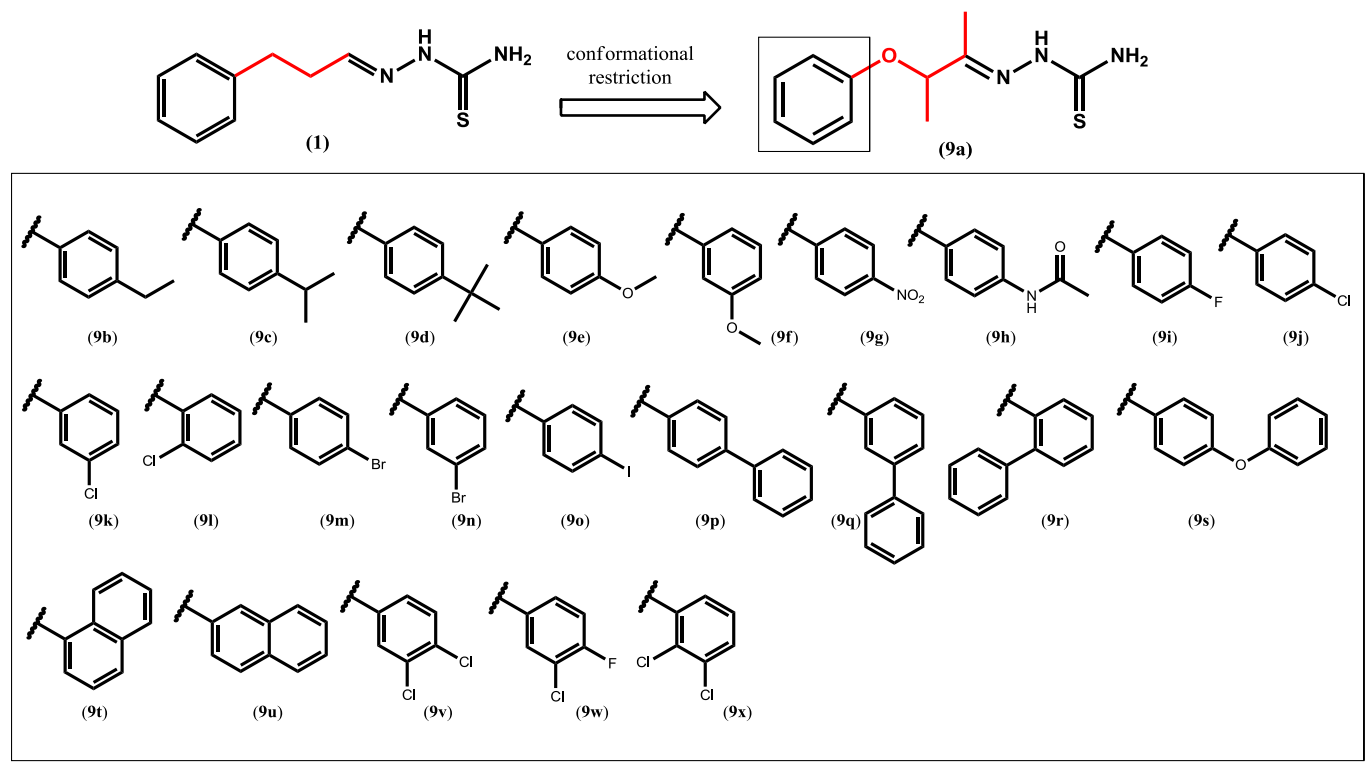

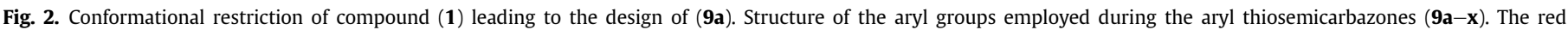
highlights the spacer groups. (For interpretation of the references to color in this figure legend, the reader is referred to the web version of this article.)

(>95\%) in yields ranging from 36 to $98 \%$. The structures were determined by ${ }^{1} \mathrm{H}$ and ${ }^{13} \mathrm{C}$ NMR, DEPT, IR and high-resolution mass.

Two diastereoisomers can be produced from these thiosemicarbazones (Fig. 3). However, when the ${ }^{1} \mathrm{H}$ NMR spectra and thin-layer chromatography were analyzed, only the formation of one isomer was observed. These results are consistent with the synthetic procedures, since the last reaction step was performed under room temperature. To determine its configuration, single crystals of the thiosemicarbazone (9a) were analyzed by X-ray crystallography. As we can see from the Ortep-3 diagrams in Fig. 3, the $\mathrm{C}(2)$ atom is antiperiplanar to $\mathrm{N}(2)$ atom, therefore the thiosemicarbazone (9a) has an E-geometry in the solid state. The same kind of assignment has been described in the literature [53]. In the ${ }^{1} \mathrm{H}$ NMR spectra of all compounds $(\mathbf{9 a}-\mathbf{x})$, the chemical shift of the methine proton $C(2)$ appears at a narrow range, from 4.88 to $5.15 \mathrm{ppm}$. Based on these findings, it is reasonable to suggest that thiosemicarbazones have an E-geometry. Due to the presence of asymmetric $\mathrm{C} 1$ carbon, specific optical rotation was examined and revealed that all analyzed thiosemicarbazones have small optical rotation activity, suggesting that the enantiomeric excess in these compounds is low.

\subsection{Pharmacological evaluation}

After structural characterization of aryl thiosemicarbazones $(\mathbf{9 a}-\mathbf{x})$, the antiparasitic and host cell cytotoxicity was determined. First, compounds were evaluated by their ability to inhibit the epimastigote proliferation of T. cruzi Dm28 strain, as well as the toxicity against trypomastigotes of $\mathrm{Y}$ strain. Results were respectively expressed in terms of $\mathrm{IC}_{50}$ and $\mathrm{CC}_{50}$ values. Following this, cytotoxicity was determined in splenocytes of BALB/c mouse and results were expressed as the highest non-toxic concentration (HNC) and given in $\mu \mathrm{M}$. Benznidazole and nifurtimox were used as reference anti-T. cruzi drugs (Table 1 ). Benznidazole exhibited a $\mathrm{CC}_{50}=6.2 \mu \mathrm{M}$ against trypomastigotes. The cutoff between active and inactive compounds was determined using the $\mathrm{CC}_{50}=6.2 \mu \mathrm{M}$ against trypomastigotes, and were considered active anti-T. cruzi agents [54].<smiles>CC(=O)[Al]OC(C)C(C)=O</smiles><smiles>CSC(N)=S</smiles>

(B)<smiles>C/C(=N\NC(N)=S)C(C)O[Ga]</smiles>

$$
\begin{aligned}
& \text { Comp. Ar } \\
& \text { (a) } \mathrm{C}_{6} \mathrm{H}_{5} \\
& \text { (b) } 4-\mathrm{EtC}_{6} \mathrm{H}_{4} \\
& \text { (c) } 4-i \mathrm{PrC}_{6} \mathrm{H}_{4} \\
& \text { (d) } 4-t \mathrm{BuC}_{6} \mathrm{H}_{4} \\
& \text { (e) } 4-\mathrm{MeOC}_{6} \mathrm{H}_{4} \\
& \text { (f) } 3-\mathrm{MeOC}_{6} \mathrm{H}_{4} \\
& \text { (g) } 4-\mathrm{NO}_{2} \mathrm{C}_{6} \mathrm{H}_{4} \\
& \text { (h) } 4 \text {-(Ac) } \mathrm{NHC}_{6} \mathrm{H}_{4}
\end{aligned}
$$
(q) $\quad 3-\left(\mathrm{C}_{6} \mathrm{H}_{5}\right) \mathrm{C}_{6} \mathrm{H}_{4}$
(r) $2-\left(\mathrm{C}_{6} \mathrm{H}_{5}\right) \mathrm{C}_{6} \mathrm{H}_{4}$
(s) $\quad 4-\left(\mathrm{C}_{6} \mathrm{H}_{5} \mathrm{O}\right) \mathrm{C}_{6} \mathrm{H}_{4}$
(t) $\alpha$-Naphthyl
(u) $\beta$-Naphthyl
(v) $3,4-d i \mathrm{ClC}_{6} \mathrm{H}_{3}$
(w) $3-\mathrm{Cl}, 4-\mathrm{FC}_{6} \mathrm{H}_{3}$

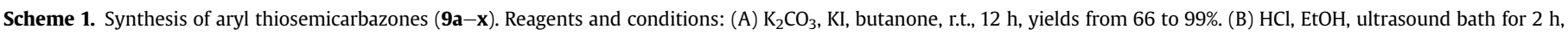
yields from 36 to $98 \%$. Ac $=$ acetyl, $i \mathrm{Pr}=$ isopropyl, $t \mathrm{Bu}=$ tertbutyl. 
<smiles>C/C(=N\NC(N)=S)C(C)Oc1ccccc1</smiles><smiles>C/C(=N/NC(N)=S)C(C)Oc1ccccc1</smiles>
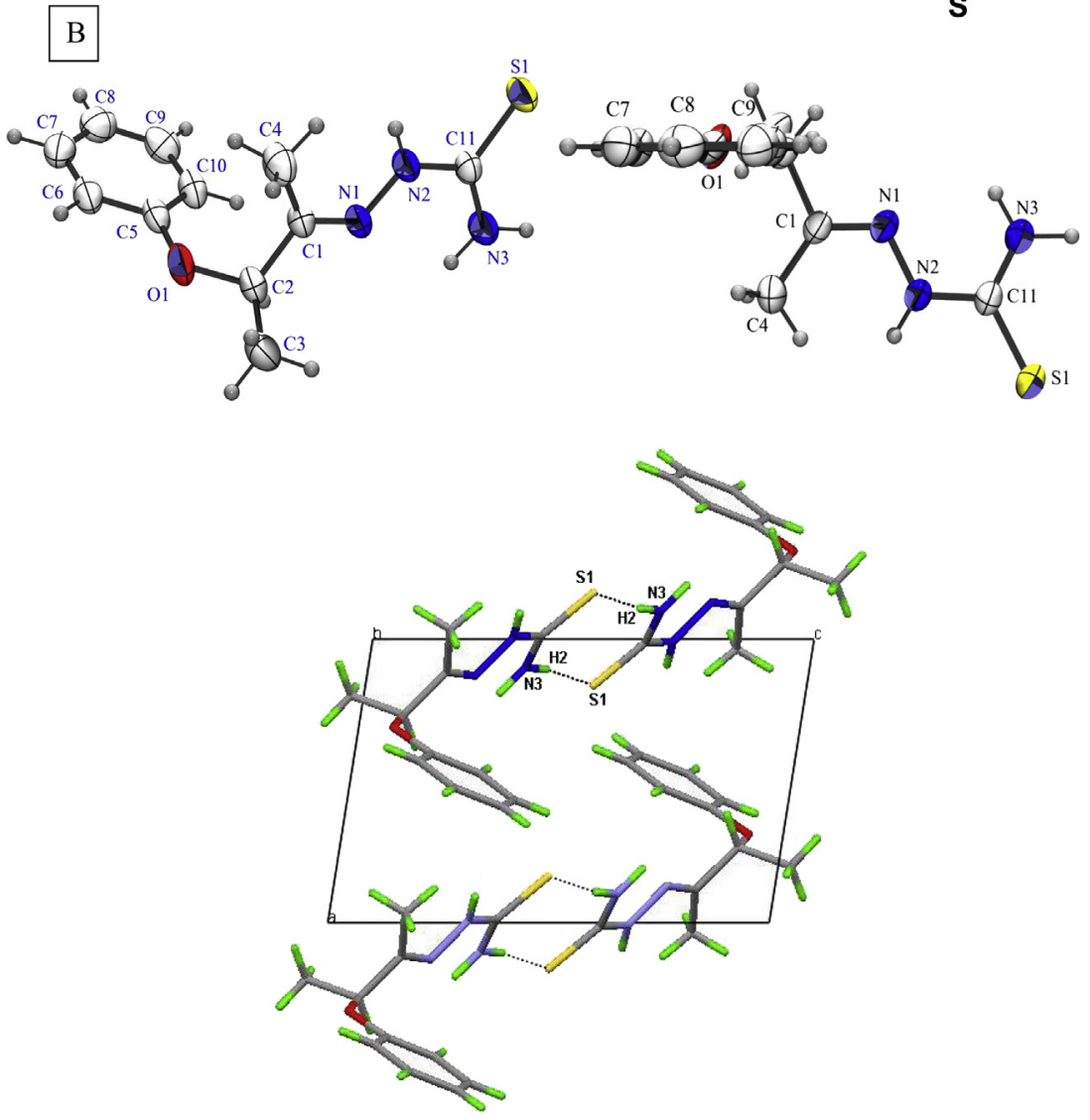

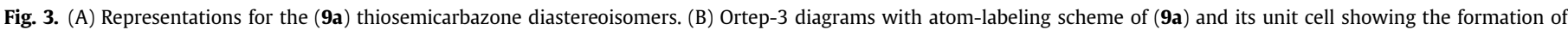
centrosymmetric dimmers. Displacement ellipsoids are shown at the 50\% probability level.

Regarding the activity against trypomastigotes, nonsubstituted phenyl thiosemicarbazone (9a) was inactive. In comparison to (9a), anti-T. cruzi activity was enhanced when an alkyl group was attached to 4-position of the phenyl ring. The 4-ethylphenyl derivative (9b) was 6-times more potent than (9a). When a 4-isopropyl (9c) or a 4-tertbutyl (9d) substituent is attached to the phenyl ring, the resulting thiosemicarbazones were twice as potent as benznidazole. The 4-methoxyphenyl derivative (9e) was inactive, while its isomer (3-methoxyphenyl, 9f) was active. However, the insertion of a 3-methoxyphenyl was not enough to produce a compound more potent than benznidazole. In comparison to a nonsubstituted phenyl thiosemicarbazone (9a), a 4-nitro group (9g) enhanced the anti-T. cruzi activity. More remarkably, attaching an acetamide group (9h) greatly increased the anti-T. cruzi activity. In fact, the potency of $(\mathbf{9 h})$ against trypomastigotes was very similar to that observed for nifurtimox and twice as potent as benznidazole.

We evaluated the activity against trypomastigotes for thiosemicarbazones containing halogen atoms attached to the phenyl ring. In these conditions, 4-fluorophenyl (9i) and 4-chlorophenyl (9j) derivatives were inactive. However, when the position of the chloro atom was changed, the potency increased with the following order: $(2-\mathrm{Cl}, \mathbf{9 l})>(3-\mathrm{Cl}, \mathbf{9 k})>(4-\mathrm{Cl}, \mathbf{9 j})$. Bromo atom attachment greatly increases the activity, regardless of its position in the phenyl ring. Likewise, attaching an iodo atom $(\mathbf{9 o})$ greatly increases the activity in comparison to nonsubstituted phenyl thiosemicarbazone (9a). Based on the results with bromo and iodo, we evaluated compounds containing biphenyl groups. Placing a biphenyl greatly increased activity against trypomastigotes. When we analyzed the $\mathrm{CC}_{50}$ values for compounds ( $4^{\prime}$-phenyl, 9p), ( $3^{\prime}$ phenyl, 9q) and ( $2^{\prime}$-phenyl, 9r), we observed that the position of the biphenyl group did not affect potency. Interestingly, the 4-(phenoxy)phenyl derivative (9s) was very active against trypomastigotes, exhibiting a $\mathrm{CC}_{50}$ value in the same range of the thiosemicarbazones containing biphenyl groups.

Next, we tested thiosemicarbazones containing a naphthyl, as opposed to a phenyl ring. While the phenyl thiosemicarbazone (9a) is inactive, the $\alpha$-naphthyl (9t) and the $\beta$-naphthyl (9u) 
Table 1

Anti-T. cruzi activity and host cell toxicity for thiosemicarbazones $(\mathbf{9 a}-\mathbf{x})$.

\begin{tabular}{|c|c|c|c|c|}
\hline \multirow[t]{2}{*}{ Compd. } & \multirow[t]{2}{*}{$\mathrm{Ar}$} & \multicolumn{2}{|l|}{ T. cruzi } & \multirow[t]{2}{*}{ Cytotoxicity, HNC $(\mu \mathrm{M})^{c}$} \\
\hline & & $\mathrm{IC}_{50}(\mu \mathrm{M})$ epimastigotes ${ }^{\mathrm{a}}$ & $\mathrm{CC}_{50}(\mu \mathrm{M})$ trypomastigotes $^{\mathrm{b}}$ & \\
\hline$(9 a)$ & $\mathrm{C}_{6} \mathrm{H}_{5}$ & 26.1 & 27.3 & 210.6 \\
\hline$(9 b)$ & $4-\mathrm{EtC}_{6} \mathrm{H}_{4}$ & 11.6 & 4.6 & 18.8 \\
\hline (9c) & 4-i $\mathrm{PrC}_{6} \mathrm{H}_{4}$ & 5.9 & 1.5 & 17.9 \\
\hline (9d) & 4- $t \mathrm{BuC}_{6} \mathrm{H}_{4}$ & 4.6 & 1.4 & 17.0 \\
\hline$(9 \mathbf{e})$ & $4-\mathrm{MeOC}_{6} \mathrm{H}_{4}$ & 27.6 & 26.8 & 93.5 \\
\hline (9f) & $3-\mathrm{MeOC}_{6} \mathrm{H}_{4}$ & 6.8 & 6.2 & 37.4 \\
\hline$(9 \mathrm{~g})$ & $4-\mathrm{NO}_{2} \mathrm{C}_{6} \mathrm{H}_{4}$ & 176.9 & 5.9 & 88.5 \\
\hline$(9 h)$ & 4-(Ac) $\mathrm{NHC}_{6} \mathrm{H}_{4}$ & 71.5 & 1.4 & $>339.7(350)^{\mathrm{d}}$ \\
\hline$(9 \mathbf{i})$ & $4-\mathrm{FC}_{6} \mathrm{H}_{4}$ & 86.4 & 23.2 & $>391.8$ \\
\hline$(\mathbf{9 j})$ & $4-\mathrm{ClC}_{6} \mathrm{H}_{4}$ & 13.5 & 22.8 & 92.0 \\
\hline (9k) & $3-\mathrm{ClC}_{6} \mathrm{H}_{4}$ & 45.8 & 5.5 & 36.8 \\
\hline (91) & $2-\mathrm{ClC}_{6} \mathrm{H}_{4}$ & 10.3 & 1.5 & 36.8 \\
\hline$(9 \mathrm{~m})$ & $4-\mathrm{BrC}_{6} \mathrm{H}_{4}$ & 20.1 & 3.9 & 31.6 \\
\hline$(9 n)$ & $3-\mathrm{BrC}_{6} \mathrm{H}_{4}$ & 5.8 & 4.5 & 31.6 \\
\hline$(90)$ & $4-\mathrm{IC}_{6} \mathrm{H}_{4}$ & 4.9 & 1.1 & 13.7 \\
\hline$(9 p)$ & $4-\left(\mathrm{C}_{6} \mathrm{H}_{5}\right) \mathrm{C}_{6} \mathrm{H}_{4}$ & 4.5 & 1.3 & 15.9 \\
\hline$(9 \mathbf{q})$ & $3-\left(\mathrm{C}_{6} \mathrm{H}_{5}\right) \mathrm{C}_{6} \mathrm{H}_{4}$ & 2.2 & 1.3 & 31.9 \\
\hline$(9 r)$ & $2-\left(\mathrm{C}_{6} \mathrm{H}_{5}\right) \mathrm{C}_{6} \mathrm{H}_{4}$ & 2.2 & 1.1 & $31.9(50)^{\mathrm{d}}$ \\
\hline$(9 s)$ & $4-\left(\mathrm{C}_{6} \mathrm{H}_{5} \mathrm{O}\right) \mathrm{C}_{6} \mathrm{H}_{4}$ & ND & 1.3 & 30.3 \\
\hline$(9 t)$ & $\alpha$-Naphthyl & 4.9 & 1.5 & 34.8 \\
\hline$(9 \mathbf{u})$ & $\beta$-Naphthyl & 17.9 & 5.6 & 34.8 \\
\hline$(9 v)$ & $3,4-d i \mathrm{ClC}_{6} \mathrm{H}_{3}$ & 4.4 & 4.4 & 16.3 \\
\hline$(9 w)$ & $3-\mathrm{Cl}-4-\mathrm{FC}_{6} \mathrm{H}_{3}$ & ND & 3.5 & 34.5 \\
\hline$(9 \mathbf{x})$ & $2,3-\operatorname{diClC}_{6} \mathrm{H}_{3}$ & 2.2 & 11.9 & 32.6 \\
\hline Bdz & - & 48.8 & 6.2 & 96.0 \\
\hline $\mathbf{N f x}$ & - & 5.7 & 2.7 & 3.4 \\
\hline
\end{tabular}

HNC = highest non-cytotoxic concentration.

$\mathrm{Bdz}=$ benznidazole.

$\mathrm{Nfx}=$ nifurtimox.

$\mathrm{ND}=$ not determined

a Determined 5 days after incubation with compounds, using Dm28c epimastigotes.

b Determined $24 \mathrm{~h}$ after incubation with compounds, using Y strain trypomastigotes.

c Cell viability of BALB/c mouse splenocytes determined $24 \mathrm{~h}$ after treatment.

d In parenthesis, $\mathrm{CC}_{50}$ values against mouse splenocytes. $\mathrm{IC}_{50}=$ inhibitory concentration for $50 \%$. $\mathrm{CC}_{50}=$ cytotoxic concentration for $50 \%$. $\mathrm{CC}_{50}$ and $\mathrm{IC}_{50}$ values were calculated using concentrations in triplicate and experiment was repeated, only values with a standard deviation $<10 \%$ mean were considered.

thiosemicarbazones were active. In addition to evaluating compounds with a monosubstituted phenyl ring, we tested the thiosemicarbazones containing two substituents attached to the phenyl ring. While the 4-chlorophenyl (9j) was inactive, the 3,4-dichlorophenyl derivative $(\mathbf{9 v})$ was active. The same was observed for the 3-chloro-4-fluorophenyl derivative (9w). However, attaching chloro atoms at the positions 2- and 3-(9x) slightly decreased the activity against trypomastigotes in comparison to the 3,4-dichlorophenyl derivative (9v).

Having ascertained the antiparasitic activity for trypomastigotes, we analyzed the antiproliferative activity against epimastigotes. Excluding $(\mathbf{9 g})$ and $(\mathbf{9 h})$, most compounds which were active against trypomastigotes were also able to inhibit epimastigote proliferation. Regarding cytotoxicity in splenocytes, some of the thiosemicarbazones that were active against $T$. cruzi exhibited low cytotoxicity. For instance, compounds (9h), (9r), (9s) and $(\mathbf{9 t})$ had $\mathrm{CC}_{50}<1.5 \mu \mathrm{M}$ against trypomastigotes, while they were non-toxic for splenocytes at concentrations up to $30 \mu \mathrm{M}$. Compounds (9c), (9d), (9o), (9p) and $(\mathbf{9 v})$ were the most cytotoxic thiosemicarbazones for splenocytes, albeit less cytotoxic than nifurtimox. We determined the selectivity index ( $\mathrm{CC}_{50}$ splenocytes/ $\mathrm{CC}_{50}$ trypomastigotes) for compound (9h) and (9r). They displayed indexes 250 and 45, respectively.

We investigated the inhibitory activity for thiosemicarbazones $(\mathbf{9 a}-\mathbf{x})$ against cruzain. To this, we selected thiosemicarbazones with $\mathrm{CC}_{50}<5.0 \mu \mathrm{M}$ against trypomastigotes (i.e., derivatives $\mathbf{9 g}, \mathbf{9 h}$, 9k, 9m, 9n, 9o, 9p, 9s, 9t). For comparison reasons only, we included the nonsubstituted phenyl derivative (9a). We measured cruzain mediated enzymatic activity inhibition by using an assay based on competition with the substrate Z-FR-AMC [55].
Compounds (9a), (9h), (9k), (9m), (9n), (9o) and $(\mathbf{9 s})$ were screened at $100 \mu \mathrm{M}$, while compounds $(\mathbf{9 g}),(\mathbf{9 p})$ and $(\mathbf{9 t})$ were tested at $50 \mu \mathrm{M}$, the maximum concentration at which they were soluble in the assay buffer. However, cruzain inhibition by these compounds was not observed (data not shown).

To understand the parasite death process caused by thiosemicarbazones, untreated and treated trypomastigotes were treated for $24 \mathrm{~h}$ of incubation and then double labeled with annexin V-fluorescein isothiocyanate (FITC) and propidium iodide (PI) [56]. For this assay, compounds $(\mathbf{9 h}, \mathbf{9 r})$ and $(\mathbf{9 k})$ were selected because they contain electron-donor and electron-withdrawing substituents, respectively, and assayed in concentrations equal to the $\mathrm{CC}_{25}$ and $\mathrm{CC}_{100}$. The data were acquired and analyzed by flow cytometry and results are shown in Fig. 4. In comparison to untreated parasites, treatment with thiosemicarbazones $(\mathbf{9 h}, \mathbf{9 k}$ and 9r) decreased parasite cell viability. Until $24 \mathrm{~h}$ of treatment with compounds (9h) and (9k), only few parasite cells were stained (data not shown) while in contrast, an increase in the percentage of stained parasites was observed during thiosemicarbazone (9r) treatment and this was concentration-dependent. Parasites treated with compound (9r) at $1.1 \mu \mathrm{M}$ presented $18.62 \%$ positively stained cells, of which $7.8 \%$ were early apoptotic (annexin V), $6.2 \%$ were late apoptotic (PI + annexin V), while only $4.62 \%$ were necrotic (PI).

\section{Discussion}

Currently, the only available treatment of Chagas disease is benznidazole, therefore identification of new pharmaceuticals is vital [4]. Aryl thiosemicarbazones were previously demonstrated to act as strong anti-T. cruzi agents, targeting the trypanosomal 
A

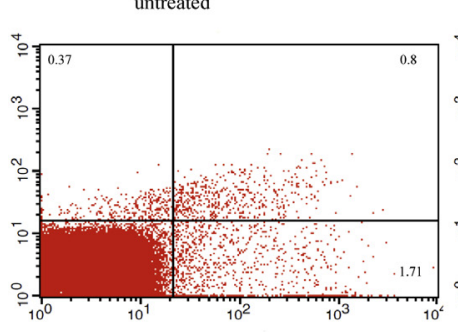

(9r), $0.25 \mu \mathrm{M}$

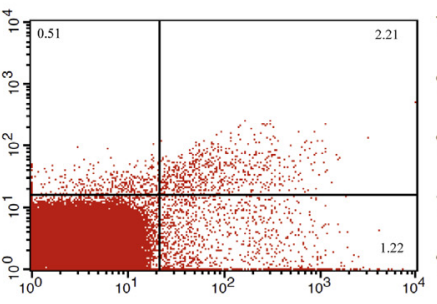

(9r), $1.1 \mu \mathrm{M}$

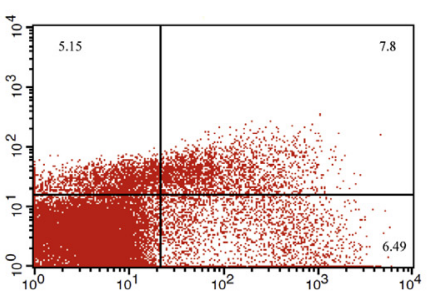

B

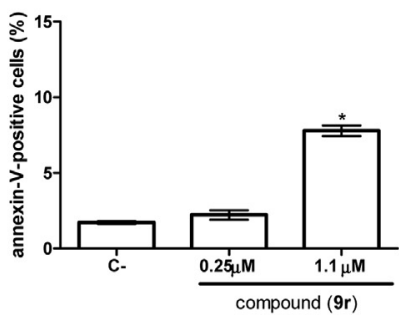

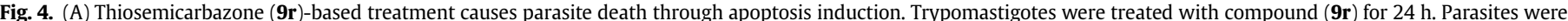

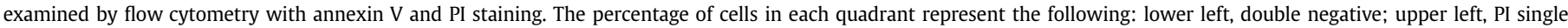

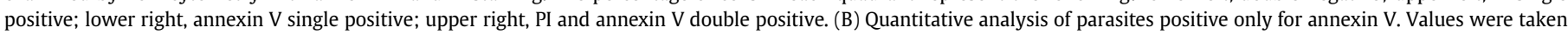
from six different readings of two independent experiments. $(\mathrm{C}-)=$ negative control. *Compared to negative control (ANOVA one-way, $p<0.05$ ).

protease cruzain [28-30]. It was recently discovered a sub-class of these inhibitors, which contains a spacer group between aryl ring and thiosemicarbazone, with an enhanced anti-T. cruzi activity in comparison to aryl thiosemicarbazones without the spacer group. Interestingly, the use of a spacer group not only enhanced the thiosemicarbazone activity, but also thiazole and thiazolidinone compound activity [40-43].

In the current study, we sought to use an alkoxyl spacer group to design new aryl thiosemicarbazones. By using the alkoxyl spacer group and varying a number of different substituents attached to the phenyl ring, we were able to observe some structural determinants involved in anti-T. cruzi activity. Specifically, substituents were observed to retain, enhance or greatly increase the anti-T. cruzi activity in comparison to the nonsubstituted phenyl thiosemicarbazone. For instance, the attachment of a 4-methoxyl, 4-fluoro or 4-chloro substituents to the phenyl ring led to derivatives that retained activity in comparison to the nonsubstituted thiosemicarbazone. However these compounds showed lower potency than benznidazole.

Next, we observed that bromo, biphenyl and phenoxyl at 4position are substituents that greatly increase the anti-T. cruzi activity in comparison to the nonsubstituted phenyl thiosemicarbazone. In agreement with activity observed for the biphenyl derivatives, the replacement of a phenyl group by a $\alpha$ - or $\beta$-naphthyl group also increased the activity. These results demonstrate that hydrophobic substituents may be structural determinants. However, we also observed that, while the derivative containing an isopropyl, tertbutyl and iodo substituents greatly increased the anti-T. cruzi activity, an unusual cytotoxicity for host cells was observed.

An interesting structure-activity relationship was observed by comparing the 4-nitrophenyl and 4-acetamidephenyl derivatives. Nitro is a well-known antiparasitic pharmacophoric group [57], but here its attachment to the phenyl ring was not effective to produce a compound as potent as benznidazole. On the other hand, the insertion of an acetamide greatly increased the activity in comparison to the nonsubstituted phenyl thiosemicarbazone. In fact, inserting an acetamide group produced one of the most potent anti-T. cruzi thiosemicarbazones observed in this study.

Another set of interesting structure-activity relationships were observed by comparing the substituent position (i.e, ortho, meta, para). It was evaluated one representative electron-donor substituent, which was the biphenyl group, and one electron-withdrawing substituent, the chloro. Variations in the position of the chloro atom when attached to the phenyl group increased the anti-T. cruzi activity. The position of biphenyl substituents within the phenyl ring did not result in potency variations. This suggests the nature of the substituent is important for the activity, but in same cases, substituent position along the phenyl ring is of less importance.
Next, the effect of electron-donor or electron-withdrawing properties of the substituents was examined here. In regard to moderate electron-donor substituents, the 4-methoxyl derivative was inactive, while the 4-phenoxyl and 4-acetamide were active. Weak electron-donor substituents, such as alkyl and phenyl, also produced active compounds. In regard to electron-withdrawing substituents, strong deactivating substituents, such as the nitro group, produced active compounds. However, bromo and iodo, which are weak electron-withdrawing substituents, produced active compounds and they were more potent than the nitro derivative. This shows that the activity cannot be explained by the substituent effect in terms of aryl reactivity. Considering that the thiosemicarbazones containing halogens, biphenyl or phenoxyl substituents exhibited the highest anti-T. cruzi activity, factors such as hydrophobic properties, volume and polarisability (in the presence of halogens) could contribute to the observed activity [58]. An exception to this general rule is the acetamide substituent, which does not fit into these factors, but this substituent produced a highly potent antiparasitic compound.

In general, the thiosemicarbazones were able to reduced epimastigote proliferation with $\mathrm{IC}_{50}$ values similar to nifurtimox. In addition, these compounds exhibited, in most cases, low cytotoxicity for host cells in comparison to the anti-T. cruzi drugs, benznidazole and nifurtimox. Specifically, compound (9h) and (9r) displayed selectivity indexes comparable with some anti-T. cruzi lead-compounds described in the literature $[13,59,60]$. Another important comparison is that the antiparasitic activity and selectivity observed for these molecules are higher than the thiosemicarbazone previously investigated $\left(\mathbf{1}, C_{50}=3.7 \mu \mathrm{M}\right.$ for trypomastigotes and $\mathrm{HNC}<1.0 \mu \mathrm{M}$ for splenocytes) [40-43]. Therefore, indicating the structural design employed here for compounds $(\mathbf{9 a}-\mathbf{x})$, which was based on the conformational restriction, was successful in producing compounds with enhanced anti-trypanosomal activity. Regarding the mechanism of action, most the literature points out that thiosemicarbazones inhibit the major trypanosomal protease, cruzain. Moreover, few reports suggest that this class of compounds also inhibits trypanothione reductase [32]. In this study, the compounds did not exhibit cruzain inhibition, thus, other mechanisms of action must be involved. Regarding the mechanism of action of parasite cell death, we observed thiosemicarbazone (9r) causes parasite death by an apoptotic process, suggesting this compound has more effects on cytoplasm and cell nucleus than affecting cell membrane.

\section{Conclusions}

Thiosemicarbazones were structurally designed by employing a homologation strategy followed by conformational restriction. This led to the synthesis and chemical characterization of compounds 
$(\mathbf{9 a}-\mathbf{x})$, which were evaluated as anti-T. cruzi and cruzain inhibitors. The pharmacological evaluation led to the identification of thiosemicarbazones (9h) and (9r) as potent and selective anti-T. cruzi agents, as similarly observed in benznidazole-treated cells. AntiT. cruzi activity was observed to be dependent on the nature of the employed substituent, but the substituent position in the phenyl ring had less importance for activity. Mechanistically, these compounds did not inhibit cruzain and were observed to induce parasite cell death through an apoptotic process. The data argue that the conformational restriction is a feasible strategy to modify the structure of antiparasitic thiosemicarbazones.

\section{Experimental section}

\subsection{General}

Most the chemicals were purchased from Sigma-Aldrich (St. Louis, USA), Merck (Berlin, Germany) or Alfa-Aesar (Massachusetts, USA). Reactions in ultrasound bath were performed in a Unique EM-804 TGR instrument, with a frequency of $40 \mathrm{kHz}$ and a nominal power of $180 \mathrm{~W}$, and without external heating. Precoated aluminum sheets (silica gel 60 F254, Merck) were used for thinlayer chromatography (TLC) and spots were visualized under UV light. Elemental analysis was performed with a Carlo Erba instrument model E-1110. IR spectra in $\mathrm{KBr}$ pellets were acquired at Bruker FT-IR spectrophotometer. ${ }^{1} \mathrm{H}$ and ${ }^{13} \mathrm{C}$ NMR were recorded on a UnityPlus $400 \mathrm{MHz}$ and Bruker AMX-300 MHz spectrometer, using DMSO- $d_{6}$ as a solvent and trimethylsilane (TMS) as the internal standard. Splitting patterns were defined as; s, singlet; d, doublet; $t$, triplet; q, quartet; $m$, multiplet. Chemical shift values were given in ppm. DEPT was employed to confirm the carbon assignment. High-resolution electrospray ionization mass spectra (HRESIMS) were acquired on a nanoUPLC-Xevo G2 Tof (Waters) in the positive ionization mode. Optical rotations were recorded using a JASCO Dichron model P-2000 polarimeter using tetrahydrofuran as solvent. X-ray diffraction of compound $(\mathbf{9 a})$ was performed on an Enraf-Nonius Kappa-CCD diffractometer (95 mm CCD camera on $\kappa$ goniostat) using graphite monochromated $\mathrm{MoK} \alpha$ radiation $(0.71073 \AA)$, at room temperature.

\subsection{Synthesis of $\beta$-ketoethers (7a-x). Example for 3- phenoxybutan-2-one (7a)}

In a round bottom flask for $100 \mathrm{~mL}$, phenol (5a, $5.0 \mathrm{~g}, 53 \mathrm{mmol})$ was dissolved in $30 \mathrm{~mL}$ butanone and stirred at room temperature. $\mathrm{K}_{2} \mathrm{CO}_{3}(11 \mathrm{~g}, 80 \mathrm{mmol})$ and $\mathrm{KI}(0.8 \mathrm{~g}, 5 \mathrm{mmol})$ were added to the mixture, following by addition of 3-chloro-2-butanone $(\mathbf{6}, 5.6 \mathrm{~g}$, $53 \mathrm{mmol}$ ). The reaction mixture was then maintained under stirring for $12 \mathrm{~h}$. After this time, the precipitate was removed under filtration and rinsed with ethyl acetate, and the organic phase was washed with water, and the with saturated $\mathrm{KOH}$ solution until the complete removal of unreacted phenol. The combined organic phases were dried over anhydrous $\mathrm{Na}_{2} \mathrm{SO}_{4}$, concentrated and then dried under vacuum. The resulting product was used in the next step without further purification.

\subsection{Synthesis of thiosemicarbazones $(\mathbf{9 a}-\boldsymbol{x})$. Example for compound (9a)}

In a round bottom flask for $50 \mathrm{~mL}$, the $\beta$-ketoether (7a, $7.5 \mathrm{~g}$, $46 \mathrm{mmol}$ ) was dissolved in $15 \mathrm{mLEtOH}$, following by the addition of two drops $\mathrm{HCl}$. The flask was placed in an ultrasound bath $(40 \mathrm{kHz}$, $180 \mathrm{~W}$ ) and under sonication, $4.2 \mathrm{~g}$ ( $46 \mathrm{mmol}$ ) of thiosemicarbazide (8) was added in portions to the reaction. After $2 \mathrm{~h}$, the mixture was cooled at $0{ }^{\circ} \mathrm{C}$ and the precipitate was filtered in a Büchner funnel with a sintered disc filter, washed with cold water, ethanol and then dried over $\mathrm{SiO}_{2}$. The resulting powder was recrystallized in EtOH to yield $9.7 \mathrm{~g}$ (89\%) of colorless crystals.

\subsubsection{2-(3-Phenoxybutan-2-ylidene)thiosemicarbazide (9a)}

Yield $=89 \%$. Mp. $\left({ }^{\circ} \mathrm{C}\right): 160-162 .[\alpha]_{\mathrm{D}}^{18}=-1.1 \pm 1.1$ (c 1.0, THF). IR $(\mathrm{KBr}): 3390\left(\mathrm{NH}_{2}\right), 3228(\mathrm{~N}-\mathrm{H}), 1598(\mathrm{C}=\mathrm{N}) \mathrm{cm}^{-1} \cdot{ }^{1} \mathrm{H}$ NMR (400 MHz, DMSO- $d_{6}$ ): $\delta 1.41$ (d, $\left.3 \mathrm{H}, J 6 \mathrm{~Hz}, \mathrm{CH}_{3}\right), 1.82\left(\mathrm{~s}, 3 \mathrm{H}, \mathrm{CH}_{3}\right.$ ), 4.97 (q, 1H, J $6 \mathrm{~Hz}, \mathrm{CH}-\mathrm{O}$ ), 6.89 (d, 2H, J $6 \mathrm{~Hz}, \mathrm{ArH}$ ), 6.97 (d, 2H, $6 \mathrm{~Hz}, \operatorname{ArH}), 7.25(\mathrm{t}, 1 \mathrm{H}, J 8.1 \mathrm{~Hz}, \mathrm{ArH}), 7.83\left(\mathrm{~s}, 1 \mathrm{H}, \mathrm{NH}_{2}\right), 8.24(\mathrm{~s}, 1 \mathrm{H}$, $\left.\mathrm{NH}_{2}\right), 10.18(\mathrm{~s}, 1 \mathrm{H}, \mathrm{NH}) .{ }^{13} \mathrm{C}$ NMR (100 MHz, DMSO-d 6 ): $\delta 11.7\left(\mathrm{CH}_{3}\right)$, $19.5\left(\mathrm{CH}_{3}\right), 76.7(\mathrm{CH}-\mathrm{O}), 116.2(\mathrm{Ar}), 121.6(\mathrm{CH}, \mathrm{Ar}), 130.1(\mathrm{Ar}), 152.5$ $(\mathrm{C}=\mathrm{N}), 157.9(\mathrm{C}-\mathrm{O}), 179.8(\mathrm{C}=\mathrm{S})$. HRESIMS: $238.0575[\mathrm{M}+\mathrm{H}]^{+}$. Anal. Calcd. for $\mathrm{C}_{11} \mathrm{H}_{15} \mathrm{~N}_{3} \mathrm{OS}$ : C, 55.67; H, 6.37; N, 17.71. Found: $\mathrm{C}$, $56.02 ; \mathrm{H}, 6.60 ; \mathrm{N}, 17.98$. Crystallization from ethanol gave $(\mathbf{9 a})$ as light white prisms suitable for X-ray analysis. Formula: $\mathrm{C}_{11} \mathrm{H}_{15} \mathrm{~N}_{3} \mathrm{OS}$. Space group triclinic, $P$-1; Unit cell parameters: $a=7.4240(4) \AA$, $b=7.8120(3) \AA, c=11.2780(5) \AA ; \alpha=101.737(3), \beta=95.465(2)$, $\gamma=105.084(3)$.

\subsubsection{2-(3-(4-Ethylphenoxy)butan-2-ylidene)thiosemicarbazide} (9b)

Recrystallization in ethanol afforded yellowish crystals, yield $=72 \%$. M.p. $\left({ }^{\circ} \mathrm{C}\right): 87-89 .[\alpha]_{\mathrm{D}}^{18}=+2.7 \pm 1.3($ c 1.0, THF). IR $(\mathrm{KBr})$ : $3491\left(\mathrm{NH}_{2}\right), 3192(\mathrm{NH}), 1571(\mathrm{C}=\mathrm{N}) \mathrm{cm}^{-1}$. ${ }^{1} \mathrm{HNMR}(400 \mathrm{MHz}$, DMSO$\left.d_{6}\right): \delta 1.13\left(\mathrm{t}, 3 \mathrm{H}, J 7.6 \mathrm{~Hz}, \mathrm{CH}_{3}\right), 1.40\left(\mathrm{~d}, 3 \mathrm{H}, J 6.4 \mathrm{~Hz}, \mathrm{CH}_{3}\right), 1.82(\mathrm{~s}, 3 \mathrm{H}$, $\left.\mathrm{CH}_{3}\right), 2.51\left(\mathrm{q}, 2 \mathrm{H}, J 7.6 \mathrm{~Hz}, \mathrm{CH}_{2}\right), 4.92(\mathrm{q}, 1 \mathrm{H}, J 6.4 \mathrm{~Hz}, \mathrm{CH}), 6.88(\mathrm{~d}, 2 \mathrm{H}, J$ $8.4 \mathrm{~Hz}, \mathrm{ArH}), 7.07$ (d, 2H, J 8.4 Hz, ArH), $7.82\left(\mathrm{~s}, 1 \mathrm{H}, \mathrm{NH}_{2}\right), 8.23(\mathrm{~s}, 1 \mathrm{H}$, $\left.\mathrm{NH}_{2}\right), 10.16(\mathrm{~s}, 1 \mathrm{H}, \mathrm{NH}) .{ }^{13} \mathrm{C}$ NMR $\left(75.5 \mathrm{MHz}\right.$, DMSO-d $\left.d_{6}\right): \delta 10.9\left(\mathrm{CH}_{3}\right)$, $15.7\left(\mathrm{CH}_{3}\right), 18.8\left(\mathrm{CH}_{3}\right), 27.2\left(\mathrm{CH}_{2}\right), 76.2(\mathrm{CH}), 115.5(\mathrm{CH}, \mathrm{Ar}), 128.6(\mathrm{CH}$, $\mathrm{Ar}), 136.2(\mathrm{Ar}), 152.0(\mathrm{C}-\mathrm{O}), 155.2(\mathrm{C}=\mathrm{N}), 179.1(\mathrm{C}=\mathrm{S})$. HRESIMS: 266.1264 [M] ${ }^{+}$. Anal. Calcd. for $\mathrm{C}_{13} \mathrm{H}_{19} \mathrm{~N}_{3} \mathrm{OS}$ : C, 58.84; H, 7.22; N, 15.83. Found: C, 59.11; H, 6.70; N, 16.42 .

\subsubsection{2-(3-(4-Isopropylphenoxy)butan-2-ylidene)} thiosemicarbazide $(\mathbf{9 c})$

Recrystallization in ethanol afforded colorless crystals, yield $=55 \%$. M.p. $\left({ }^{\circ} \mathrm{C}\right): 106-108 . \mathrm{IR}(\mathrm{KBr}): 3492\left(\mathrm{NH}_{2}\right), 3193(\mathrm{NH})$, $1571(\mathrm{C}=\mathrm{N}) \mathrm{cm}^{-1}$. ${ }^{1} \mathrm{H}$ NMR $\left(300 \mathrm{MHz}, \mathrm{DMSO}-d_{6}\right): \delta 1.14(\mathrm{~d}, 6 \mathrm{H}, J 6.4$ $\left.\mathrm{Hz}, \mathrm{CH}_{3}\right), 1.39$ (d, 3H, J 6.4 Hz, $\left.\mathrm{CH}_{3}\right), 1.82\left(\mathrm{~s}, 3 \mathrm{H}, \mathrm{CH}_{3}\right), 2.74-2.84(\mathrm{~m}$, $1 \mathrm{H}, \mathrm{CH}), 4.91$ (q, 1H, J $6.4 \mathrm{~Hz}, \mathrm{CH}-\mathrm{O}), 6.88$ (d, 2H, J $8.8 \mathrm{~Hz}, \mathrm{ArH}), 7.10$ $(\mathrm{d}, 2 \mathrm{H}, J 8.8 \mathrm{~Hz}, \mathrm{ArH}), 7.81\left(\mathrm{~s}, 1 \mathrm{H}, \mathrm{NH}_{2}\right), 8.23\left(\mathrm{~s}, 1 \mathrm{H}, \mathrm{NH}_{2}\right), 10.16(\mathrm{~s}, 1 \mathrm{H}$, $\mathrm{NH}) .{ }^{13} \mathrm{C}$ NMR $\left(100 \mathrm{MHz}\right.$, DMSO-d $\left.d_{6}\right): \delta 10.9\left(\mathrm{CH}_{3}\right), 18.8\left(\mathrm{CH}_{3}\right), 24.0$ $\left(\mathrm{CH}_{3}\right), 24.0\left(\mathrm{CH}_{3}\right), 32.5(\mathrm{CH}), 76.1(\mathrm{CH}-\mathrm{O}), 115.3(\mathrm{CH}, \mathrm{Ar}), 127.1(\mathrm{CH}$, Ar), $140.7(\mathrm{CH}, \mathrm{Ar}), 152.1(\mathrm{C}-\mathrm{O}), 155.3(\mathrm{C}=\mathrm{N}), 179.1(\mathrm{C}=\mathrm{S})$. HRESIMS: $280.1516[\mathrm{M}]^{+}$. Anal. Calcd. for $\mathrm{C}_{14} \mathrm{H}_{21} \mathrm{~N}_{3} \mathrm{OS}$ : C, 60.18; $\mathrm{H}, 7.58$; $\mathrm{N}, 15.04$. Found: C, 60.88; H, 6.54; N, 15.76 .

\subsubsection{2-(3-(4-Tertbutylphenoxy)butan-2-ylidene)}

thiosemicarbazide (9d)

Recrystallization in methanol afforded colorless crystals, yield $=71 \%$. M.p. $\left({ }^{\circ} \mathrm{C}\right): 69-71$. IR $(\mathrm{KBr}): 3408\left(\mathrm{NH}_{2}\right), 3254(\mathrm{~N}-\mathrm{H})$, $1603(\mathrm{C}=\mathrm{N}) \mathrm{cm}^{-1} \cdot{ }^{1} \mathrm{H}$ NMR $\left(300 \mathrm{MHz}, \mathrm{DMSO}-d_{6}\right): \delta 1.23(\mathrm{~s}, 9 \mathrm{H}$, $\left.\mathrm{CH}_{3}\right), 1.40\left(\mathrm{~d}, 3 \mathrm{H}, J 6 \mathrm{~Hz}, \mathrm{CH}_{3}\right), 1.83\left(\mathrm{~s}, 3 \mathrm{H}, \mathrm{CH}_{3}\right), 4.92(\mathrm{q}, 1 \mathrm{H}, J 6 \mathrm{~Hz}$, $\mathrm{CH}), 6.89(\mathrm{~d}, 2 \mathrm{H}, J 9 \mathrm{~Hz}, \mathrm{ArH}), 7.25(\mathrm{~d}, 2 \mathrm{H}, J 9 \mathrm{~Hz}, \operatorname{ArH}), 7.83(\mathrm{~s}, 1 \mathrm{H}$, $\left.\mathrm{NH}_{2}\right), 8.25\left(\mathrm{~s}, 1 \mathrm{H}, \mathrm{NH}_{2}\right), 10.17(\mathrm{~s}, 1 \mathrm{H}, \mathrm{NH}) .{ }^{13} \mathrm{C}$ NMR and DEPT (75.5 MHz, DMSO-d $\left.d_{6}\right): \delta 16.4\left(\mathrm{CH}_{3}\right), 24.3\left(\mathrm{CH}_{3}\right), 36.7\left(\mathrm{CH}_{3}\right), 38.5$ (Cq), $81.5(\mathrm{CH}-\mathrm{O}), 120.4(\mathrm{CH}, \mathrm{Ar}), 131.5(\mathrm{CH}, \mathrm{Ar}), 148.5$ (C, Ar), 157.3 $(\mathrm{C}-\mathrm{O}), 160.4(\mathrm{C}=\mathrm{N}), 183.90(\mathrm{C}=\mathrm{S})$. HRESIMS: $293.9266[\mathrm{M}]^{+}$. Anal. Calcd. for $\mathrm{C}_{15} \mathrm{H}_{23} \mathrm{~N}_{3} \mathrm{OS}$ : C, 61.40; $\mathrm{H}, 7.90 ; \mathrm{N}, 14.32$. Found: $\mathrm{C}, 60.66 ; \mathrm{H}$, $6.88 ; \mathrm{N}, 14.44$. 


\subsubsection{2-(3-(4-Methoxyphenoxy)butan-2-ylidene)}

thiosemicarbazide $(\mathbf{9 e})$

Recrystallization in ethanol afforded yellowish crystals, yield $=92 \%$. M.p. $\left({ }^{\circ} \mathrm{C}\right): 120-122 . \mathrm{IR}(\mathrm{KBr}): 3393\left(\mathrm{NH}_{2}\right), 3224(\mathrm{~N}-\mathrm{H})$, $1600(\mathrm{C}=\mathrm{N}) \mathrm{cm}^{-1}$. ${ }^{1} \mathrm{H}$ NMR $\left(300 \mathrm{MHz}, \mathrm{DMSO}-d_{6}\right): \delta 1.38(\mathrm{~d}, 3 \mathrm{H}, J 6.6$ $\left.\mathrm{Hz}, \mathrm{CH}_{3}\right), 1.82\left(\mathrm{~s}, 3 \mathrm{H}, \mathrm{CH}_{3}\right), 3.68\left(\mathrm{~s}, 3 \mathrm{H}, \mathrm{OCH}_{3}\right), 4.85(\mathrm{q}, 1 \mathrm{H}, J 6.6 \mathrm{~Hz}$, $\mathrm{CH}-\mathrm{O}), 6.80(\mathrm{~d}, 2 \mathrm{H}, J 9 \mathrm{~Hz}, \mathrm{ArH}), 6.90(\mathrm{~d}, 2 \mathrm{H}, J 9 \mathrm{~Hz}, \mathrm{ArH}), 7.79(\mathrm{~s}, 1 \mathrm{H}$, $\left.\mathrm{NH}_{2}\right), 8.23\left(\mathrm{~s}, 1 \mathrm{H}, \mathrm{NH}_{2}\right), 10.16(\mathrm{~s}, 1 \mathrm{H}, \mathrm{NH}) .{ }^{13} \mathrm{C}$ NMR $(75.5 \mathrm{MHz}$, DMSO-d $\left.d_{6}\right): \delta 10.9\left(\mathrm{CH}_{3}\right), 18.8\left(\mathrm{CH}_{3}\right), 55.2\left(\mathrm{OCH}_{3}\right), 76.7(\mathrm{CH}-\mathrm{O}), 114.4$ $(\mathrm{CH}, \mathrm{Ar}), 116.7(\mathrm{CH}, \mathrm{Ar}), 151.0(\mathrm{C}-\mathrm{O}), 152.1(\mathrm{C}-\mathrm{O}), 153.5(\mathrm{C}=\mathrm{N}), 179.1$ $(\mathrm{C}=\mathrm{S})$. HRESIMS: $268.0632[\mathrm{M}+\mathrm{H}]^{+}$. Anal. Calcd. for $\mathrm{C}_{12} \mathrm{H}_{17} \mathrm{~N}_{3} \mathrm{O}_{2} \mathrm{~S}$ : C, 53.91; H, 6.41; N, 15.72. Found: C, 54.50; H, 6.53; N, 15.95.

\subsubsection{2-(3-(3-Methoxyphenoxy)butan-2-ylidene)}

thiosemicarbazide (9f)

Recrystallization in ethanol afforded yellowish crystals, yield $=52 \%$. M.p. $\left({ }^{\circ} \mathrm{C}\right): 110-112$. IR $(\mathrm{KBr}): 3403\left(\mathrm{NH}_{2}\right), 3255(\mathrm{~N}-\mathrm{H})$, $1596(\mathrm{C}=\mathrm{N}) \mathrm{cm}^{-1} .{ }^{1} \mathrm{H}$ NMR $\left(400 \mathrm{MHz}, \mathrm{DMSO}-d_{6}\right): \delta 1.40(\mathrm{~d}, 3 \mathrm{H}, J 6.6$ $\left.\mathrm{Hz}, \mathrm{CH}_{3}\right), 1.82\left(\mathrm{~s}, 3 \mathrm{H}, \mathrm{CH}_{3}\right), 3.69\left(\mathrm{~s}, 3 \mathrm{H}, \mathrm{OCH}_{3}\right), 4.94(\mathrm{q}, 1 \mathrm{H}, J 6.6 \mathrm{~Hz}$, $\mathrm{CH}-\mathrm{O}), 6.48-6.56(\mathrm{~m}, 3 \mathrm{H}, \mathrm{ArH}), 7.14(\mathrm{t}, 1 \mathrm{H}, J 7.8 \mathrm{~Hz}, \mathrm{ArH}), 7.82(\mathrm{~s}, 1 \mathrm{H}$, $\left.\mathrm{NH}_{2}\right), 8.20\left(\mathrm{~s}, 1 \mathrm{H}, \mathrm{NH}_{2}\right), 10.16(\mathrm{~s}, 1 \mathrm{H}, \mathrm{NH}) .{ }^{13} \mathrm{C} \mathrm{NMR}(100 \mathrm{MHz}$, DMSO$\left.d_{6}\right): \delta 10.9\left(\mathrm{CH}_{3}\right), 18.7\left(\mathrm{CH}_{3}\right), 54.9\left(\mathrm{OCH}_{3}\right), 76.2(\mathrm{CH}-\mathrm{O}), 101.6(\mathrm{CH}$, $\mathrm{Ar}), 106.6(\mathrm{CH}, \mathrm{Ar}), 107.7(\mathrm{CH}, \mathrm{Ar}), 129.9(\mathrm{CH}, \mathrm{Ar}), 151.7(\mathrm{C}=\mathrm{N}), 158.4$ (C-O), $160.3(\mathrm{C}-\mathrm{O}), 179.16(\mathrm{C}=\mathrm{S})$. HRESIMS: $268.1216[\mathrm{M}+\mathrm{H}]^{+}$. Anal. Calcd. for $\mathrm{C}_{12} \mathrm{H}_{17} \mathrm{~N}_{3} \mathrm{O}_{2} \mathrm{~S}$ : C, 53.91; $\mathrm{H}, 6.41 ; \mathrm{N}, 15.72$. Found: $\mathrm{C}$, 54.15; H, 5.96; N, 15.98 .

\subsubsection{2-(3-(4-Nitrophenoxy)butan-2-ylidene)thiosemicarbazide (9g)}

Recrystallization in ethanol afforded bright yellowish crystals, yield: 87\%. M.p. $\left({ }^{\circ} \mathrm{C}\right)$ : $160-162$. IR ( $\left.\mathrm{KBr}\right): 3453\left(\mathrm{NH}_{2}\right), 3291(\mathrm{~N}-\mathrm{H})$, $1589(\mathrm{C}=\mathrm{N}) \mathrm{cm}^{-1}$. ${ }^{1} \mathrm{H}$ NMR $\left.(400 \mathrm{MHz} \text {, DMSO-d })_{6}\right): \delta 1.47(\mathrm{~d}, 3 \mathrm{H}, J 6.6$ $\left.\mathrm{Hz}, \mathrm{CH}_{3}\right), 1.85\left(\mathrm{~s}, 3 \mathrm{H}, \mathrm{CH}_{3}\right), 5.15(\mathrm{q}, 1 \mathrm{H}, J 6.6 \mathrm{~Hz}, \mathrm{CH}-\mathrm{O}), 7.20(\mathrm{~d}, 2 \mathrm{H}, J$ $9.3 \mathrm{~Hz}, \mathrm{ArH}), 7.82\left(\mathrm{~s}, 1 \mathrm{H}, \mathrm{NH}_{2}\right), 8.16(\mathrm{~d}, 2 \mathrm{H}, J 9.3 \mathrm{~Hz}, \operatorname{ArH}), 8.26(\mathrm{~s}, 1 \mathrm{H}$, $\left.\mathrm{NH}_{2}\right), 10.21(\mathrm{~s}, 1 \mathrm{H}, \mathrm{NH}) .{ }^{13} \mathrm{C} \mathrm{NMR}\left(100 \mathrm{MHz}, \mathrm{DMSO}-d_{6}\right): \delta 11.1\left(\mathrm{CH}_{3}\right)$, $18.4\left(\mathrm{CH}_{3}\right), 77.2(\mathrm{CH}-\mathrm{O}), 116.0(\mathrm{CH}, \mathrm{Ar}), 125.7(\mathrm{CH}, \mathrm{Ar}), 141.0(\mathrm{C}-\mathrm{N}$, Ar), $150.2(C=N), 162.6(C-O), 179.3(C=S)$. HRESIMS: 283.0980 $[\mathrm{M}+\mathrm{H}]^{+}$. Anal. Calcd. for $\mathrm{C}_{11} \mathrm{H}_{14} \mathrm{~N}_{4} \mathrm{O}_{3} \mathrm{~S}$ : C, 46.80; H, 5.00; N, 19.85 . Found: C, 47.63; H, 4.88; N, 19.20.

\subsection{8. $\mathrm{N}-(4-(((3-($ thiosemicarbazide)butan-2-ylidene)oxy)phenyl) acetamide $(\mathbf{9 h})$}

Recrystallization in ethanol afforded pale yellow crystals, yield $=89 \%$. M.p. $\left({ }^{\circ} \mathrm{C}\right): 177-179 .[\alpha]_{\mathrm{D}}^{18}=-2.4 \pm 5.2$ (c 1.0, THF). IR $(\mathrm{KBr}): 3406\left(\mathrm{NH}_{2}\right), 3270(\mathrm{~N}-\mathrm{H}), 1658(\mathrm{C}=\mathrm{N}) \mathrm{cm}^{-1} \cdot{ }^{1} \mathrm{H}$ NMR (300 MHz, DMSO-d $\left.d_{6}\right): \delta 1.39\left(\mathrm{~d}, 3 \mathrm{H}, J 6.3 \mathrm{~Hz}, \mathrm{CH}_{3}\right), 1.82\left(\mathrm{~s}, 3 \mathrm{H}, \mathrm{CH}_{3}\right)$, 1.99 (s, 3H, CH $), 4.89(\mathrm{q}, 1 \mathrm{H}, J 6.3 \mathrm{~Hz}, \mathrm{CH}-\mathrm{O}), 6.90$ (d, $2 \mathrm{H}, J 8.7 \mathrm{~Hz}$, $\mathrm{ArH}), 7.43(\mathrm{~d}, 2 \mathrm{H}, J 8.7 \mathrm{~Hz}, \mathrm{ArH}), 7.78\left(\mathrm{~s}, 1 \mathrm{H}, \mathrm{NH}_{2}\right), 8.19\left(\mathrm{~s}, 1 \mathrm{H}, \mathrm{NH}_{2}\right)$, 9.77 (s, 1H, NHCO), 10.11 (s, 1H, NH). ${ }^{13} \mathrm{C}$ NMR (75.5 MHz, DMSO- $\left.d_{6}\right)$ : $\delta 11.0\left(\mathrm{CH}_{3}\right), 18.4\left(\mathrm{CH}_{3}\right), 77.1(\mathrm{CH}-\mathrm{O}), 116.5(\mathrm{CH}, \mathrm{Ar}), 117.7(\mathrm{CH}, \mathrm{Ar})$, 122.9 ( $\mathrm{Ar}), 130.9(\mathrm{CH}, \mathrm{Ar}), 131.55(\mathrm{Ar}), 150.5(\mathrm{C}=\mathrm{N}), 156.7(\mathrm{C}-\mathrm{O})$, $179.3(\mathrm{~S}=\mathrm{C})$. HRESIMS: $295.0880[\mathrm{M}+\mathrm{H}]^{+}$. Anal. Calcd. for $\mathrm{C}_{13} \mathrm{H}_{18} \mathrm{~N}_{4} \mathrm{O}_{2} \mathrm{~S}$ : C, 53.04; H, 6.16; N, 19.03. Found: C, 53.29; H, 5.60; N, 19.20 .

\subsubsection{2-(3-(4-Fluorophenoxy)butan-2-ylidene)thiosemicarbazide} (9i)

Recrystallization in ethanol afforded colorless crystals, yield $=83 \%$. M.p. $\left({ }^{\circ} \mathrm{C}\right): 148-150$. IR $(\mathrm{KBr}): 3427\left(\mathrm{NH}_{2}\right), 3265(\mathrm{NH})$, $1605(\mathrm{C}=\mathrm{N}) \mathrm{cm}^{-1}$. ${ }^{1} \mathrm{H}$ NMR $(300 \mathrm{MHz}$, DMSO-d 6$): 1.40(\mathrm{~d}, 3 \mathrm{H}, J 6.8$ $\left.\mathrm{Hz}, \mathrm{CH}_{3}\right), 1.82\left(\mathrm{~s}, 3 \mathrm{H}, \mathrm{CH}_{3}\right), 4.91(\mathrm{q}, 1 \mathrm{H}, J 6.4 \mathrm{~Hz}, \mathrm{CH}-\mathrm{O}), 6.97-7.10(\mathrm{~m}$, $4 \mathrm{H}, \mathrm{ArH}), 7.81\left(\mathrm{~s}, 1 \mathrm{H}, \mathrm{NH}_{2}\right), 8.24\left(\mathrm{~s}, 1 \mathrm{H}, \mathrm{NH}_{2}\right), 10.17(\mathrm{~s}, 1 \mathrm{H}, \mathrm{NH}) .{ }^{13} \mathrm{C}$ NMR (100 MHz, DMSO-d $\left.d_{6}\right): \delta 10.9\left(\mathrm{CH}_{3}\right), 18.7\left(\mathrm{CH}_{3}\right), 76.8(\mathrm{CH}-\mathrm{O})$, 115.6 (CH, Ar), 115.9 (CH, Ar), $116.9(\mathrm{CH}, \mathrm{Ar}), 117.0(\mathrm{CH}, \mathrm{Ar}), 151.5(\mathrm{C}-$ O), $153.5(C=N), 155.4(C-F, A r), 157.8(C-F, A r), 179.1(C=S)$.
HRESIMS: $256.0987[\mathrm{M}+\mathrm{H}]^{+}$. Anal. Calcd. for $\mathrm{C}_{11} \mathrm{H}_{14} \mathrm{~N}_{3} \mathrm{OSF}$ : C, 51.75; H, 5.53; N, 16.46. Found: C, 52.18; H, 5.09; N, 17.14 .

\subsubsection{2-(3-(4-Chlorophenoxy)butan-2-ylidene)thiosemicarbazide (9j)}

Recrystallization in ethanol afforded yellowish crystals, yield $=59 \%$. M.p. $\left({ }^{\circ} \mathrm{C}\right): 119-121$. IR $(\mathrm{KBr}): 3400$ and $3353\left(\mathrm{NH}_{2}\right)$, $3246(\mathrm{~N}-\mathrm{H}), 1608(\mathrm{C}=\mathrm{N}) \mathrm{cm}^{-1} \cdot{ }^{1} \mathrm{H}$ NMR $\left(300 \mathrm{MHz}\right.$, DMSO-d $\left.d_{6}\right)$ : $\delta 1.42\left(\mathrm{~d}, 3 \mathrm{H}, J 6.6 \mathrm{~Hz}, \mathrm{CH}_{3}\right), 1.82\left(\mathrm{~s}, 3 \mathrm{H}, \mathrm{CH}_{3}\right), 4.96(\mathrm{q}, 1 \mathrm{H}, J 6.6 \mathrm{~Hz}$, $\mathrm{CH}-\mathrm{O}), 7.01(\mathrm{~d}, 2 \mathrm{H}, J 6.6 \mathrm{~Hz}, \mathrm{ArH}), 7.29(\mathrm{~d}, 2 \mathrm{H}, J 6.6 \mathrm{~Hz}, \mathrm{ArH}), 7.85(\mathrm{~s}$, $\left.1 \mathrm{H}, \mathrm{NH}_{2}\right), 8.27\left(\mathrm{~s}, 1 \mathrm{H}, \mathrm{NH}_{2}\right), 10.21(\mathrm{~s}, 1 \mathrm{H}, \mathrm{NH}) .{ }^{13} \mathrm{C} \mathrm{NMR}(75.5 \mathrm{MHz}$, DMSO-d $\left.{ }_{6}\right): \delta 11.0\left(\mathrm{CH}_{3}\right), 18.6\left(\mathrm{CH}_{3}\right), 76.5(\mathrm{CH}-\mathrm{O}), 117.4(\mathrm{CH}, \mathrm{Ar})$, $124.6(\mathrm{Ar}), 129.2(\mathrm{CH}, \mathrm{Ar}), 151.2(\mathrm{C}=\mathrm{N}), 156.0(\mathrm{C}-\mathrm{O}), 179.1(\mathrm{C}=\mathrm{S})$. HRESIMS: $272.0127[\mathrm{M}]^{+}$. Anal. Calcd. for $\mathrm{C}_{11} \mathrm{H}_{14} \mathrm{~N}_{3} \mathrm{OSCl}$ : C, 48.61; H, 5.19; N, 15.46. Found: C, 49.01; H, 5.12; N, 16.11 .

\subsubsection{2-(3-(3-Chlorophenoxy)butan-2-ylidene)thiosemicarbazide (9k)}

Recrystallization in ethanol afforded brown crystals, yield $=89 \%$. M.p. $\left({ }^{\circ} \mathrm{C}\right): 96-98 . \mathrm{IR}(\mathrm{KBr}): 3323\left(\mathrm{NH}_{2}\right), 3256(\mathrm{NH}), 1603(\mathrm{C}=\mathrm{N}) \mathrm{cm}^{-1}$. ${ }^{1} \mathrm{H}$ NMR (400 MHz, DMSO- $\left.d_{6}\right): \delta 1.41\left(\mathrm{~d}, 3 \mathrm{H}, J 6.6 \mathrm{~Hz}, \mathrm{CH}_{3}\right), 1.83(\mathrm{~s}, 3 \mathrm{H}$, $\left.\mathrm{CH}_{3}\right), 5.00$ (q, 1H, J 6.6 Hz, CH-O), 6.94-6.99 (m, 2H, Ar), 7.04-7.06 $(\mathrm{m}, 1 \mathrm{H}, \mathrm{Ar}), 7.27(\mathrm{t}, 1 \mathrm{H}, J 8.1 \mathrm{~Hz}, \mathrm{Ar}), 7.84\left(\mathrm{~s}, 1 \mathrm{H}, \mathrm{NH}_{2}\right), 8.23\left(\mathrm{~s}, 1 \mathrm{H}, \mathrm{NH}_{2}\right)$, $10.18(\mathrm{~s}, 1 \mathrm{H}, \mathrm{NH}) .{ }^{13} \mathrm{C}$ NMR $\left(100 \mathrm{MHz}, \mathrm{DMSO}-d_{6}\right): \delta 11.0\left(\mathrm{CH}_{3}\right), 18.5$ $\left(\mathrm{CH}_{3}\right), 76.6(\mathrm{CH}-\mathrm{O}), 114.5(\mathrm{CH}, \mathrm{Ar}), 115.7(\mathrm{CH}, \mathrm{Ar}), 120.9(\mathrm{CH}, \mathrm{Ar}), 130.8$ $(\mathrm{CH}, \mathrm{Ar}), 133.6(\mathrm{C}-\mathrm{Cl}), 150.9(\mathrm{C}=\mathrm{N}), 158.1(\mathrm{C}-\mathrm{O}), 179.2(\mathrm{C}=\mathrm{S})$. HRESIMS: $272.0702[\mathrm{M}+\mathrm{H}]^{+}$. Anal. Calcd. for $\mathrm{C}_{11} \mathrm{H}_{14} \mathrm{~N}_{3} \mathrm{OSCl}$ : C, 48.61; H, 5.19; N, 15.46. Found: C, 49.28; H, 5.13; N, 16.05.

\subsubsection{2-(3-(2-Chlorophenoxy)butan-2-ylidene)thiosemicarbazide (9l)}

Recrystallization in ethanol afforded yellowish crystals, yield $=69 \%$. M.p. $\left({ }^{\circ} \mathrm{C}\right): 139-141$. IR $(\mathrm{KBr}): 3410\left(\mathrm{NH}_{2}\right), 3240(\mathrm{NH})$, $1595(\mathrm{C}=\mathrm{N}) \mathrm{cm}^{-1} .{ }^{1} \mathrm{H}$ NMR $\left(300 \mathrm{MHz}, \mathrm{DMSO}-d_{6}\right): 1.46$ (d, 3H, J 6.0 $\left.\mathrm{Hz}, \mathrm{CH}_{3}\right), 1.85\left(\mathrm{~s}, 3 \mathrm{H}, \mathrm{CH}_{3}\right), 5.06(\mathrm{q}, 1 \mathrm{H}, \mathrm{J} 6.4 \mathrm{~Hz}, \mathrm{CH}-\mathrm{O}), 6.92-6.96$ (m, 1H, ArH), 7.21-7.26 (m, 2H, ArH), $7.41(\mathrm{~d}, J 7.6 \mathrm{~Hz}, 1 \mathrm{H}, \mathrm{ArH}), 7.822$ $\left(\mathrm{s}, 1 \mathrm{H}, \mathrm{NH}_{2}\right), 8.256\left(\mathrm{~s}, 1 \mathrm{H}, \mathrm{NH}_{2}\right), 10.210(\mathrm{~s}, 1 \mathrm{H}, \mathrm{NH}) \cdot{ }^{13} \mathrm{C} \mathrm{NMR}$ (75.5 MHz, DMSO-d $\left.d_{6}\right): \delta 10.9\left(\mathrm{CH}_{3}\right), 18.5\left(\mathrm{CH}_{3}\right), 77.3(\mathrm{CH}-\mathrm{O}), 115.8$ $(\mathrm{CH}, \mathrm{Ar}), 121.9(\mathrm{CH}, \mathrm{Ar}), 122.0(\mathrm{Ar}), 128.1(\mathrm{CH}, \mathrm{Ar}), 130.0(\mathrm{CH}, \mathrm{Ar})$, $150.8(\mathrm{C}-\mathrm{O}), 152.5(\mathrm{C}=\mathrm{N}), 179.2(\mathrm{C}=\mathrm{S})$. HRESIMS: 272.0702 $[\mathrm{M}+\mathrm{H}]^{+}$. Anal. Calcd. for $\mathrm{C}_{11} \mathrm{H}_{14} \mathrm{~N}_{3} \mathrm{OSCl}$ : C, 48.61; $\mathrm{H}, 5.19 ; \mathrm{N}, 15.46$. Found: C, 48.58; H, 5.18; N, 15.78 .

\subsubsection{2-(3-(4-Bromophenoxy)butan-2-ylidene)thiosemicarbazide (9m)}

Recrystallization in ethanol afforded yellowish crystals, yield $=70 \%$ M.p. $\left({ }^{\circ} \mathrm{C}\right): 141-143 . \mathrm{IR}(\mathrm{KBr}): 3393\left(\mathrm{NH}_{2}\right), 3224(\mathrm{~N}-\mathrm{H})$, $1600(\mathrm{C}=\mathrm{N}) \mathrm{cm}^{-1}$. ${ }^{1} \mathrm{H}$ NMR $\left(300 \mathrm{MHz}, \mathrm{DMSO}-d_{6}\right): \delta 1.41(\mathrm{~d}, 3 \mathrm{H}, J 6.6$ $\left.\mathrm{Hz}, \mathrm{CH}_{3}\right), 1.81\left(\mathrm{~s}, 3 \mathrm{H}, \mathrm{CH}_{3}\right), 4.95(\mathrm{q}, 1 \mathrm{H}, J 6.6 \mathrm{~Hz}, \mathrm{CH}), 6.95(\mathrm{~d}, 1 \mathrm{H}, J$ $9 \mathrm{~Hz}, \operatorname{ArH}), 7.40$ (d, $1 \mathrm{H}, J 9 \mathrm{~Hz}, \mathrm{ArH}), 7.83\left(\mathrm{~s}, 1 \mathrm{H}, \mathrm{NH}_{2}\right), 8.26(\mathrm{~s}, 1 \mathrm{H}$, $\left.\mathrm{NH}_{2}\right), 10.20(\mathrm{~s}, 1 \mathrm{H}, \mathrm{NH}) .{ }^{13} \mathrm{C} \mathrm{NMR}\left(75.5 \mathrm{MHz}, \mathrm{DMSO}-d_{6}\right): \delta 11.0\left(\mathrm{CH}_{3}\right)$, 18.6 $\left(\mathrm{CH}_{3}\right), 76.5(\mathrm{CH}-\mathrm{O}), 112.44(\mathrm{Ar}), 117.9(\mathrm{CH}, \mathrm{Ar}), 132.1(\mathrm{CH}, \mathrm{Ar})$, $151.2(\mathrm{C}=\mathrm{N}), 156.5(\mathrm{C}-\mathrm{O}), 179.1(\mathrm{C}=\mathrm{S})$. HRESIMS: 315.9171 $[\mathrm{M}+\mathrm{H}]^{+}$. Anal. Calcd. for $\mathrm{C}_{11} \mathrm{H}_{14} \mathrm{~N}_{3} \mathrm{OSBr}$ : C, 41.78; $\mathrm{H}, 4.46 ; \mathrm{N}, 13.29$. Found: C, 41.63; H, 4.52; N, 13.23.

\subsubsection{2-(3-(3-Bromophenoxy)butan-2-ylidene)thiosemicarbazide} (9n)

Recrystallization in ethanol afforded yellowish crystals, yield $=36 \%$. M.p. $\left({ }^{\circ} \mathrm{C}\right): 121-123 . \mathrm{IR}(\mathrm{KBr}): 3393\left(\mathrm{NH}_{2}\right), 3224(\mathrm{~N}-\mathrm{H})$, $1600(\mathrm{C}=\mathrm{N}) \mathrm{cm}^{-1}$. ${ }^{1} \mathrm{H}$ NMR $\left(300 \mathrm{MHz}, \mathrm{DMSO}-d_{6}\right): \delta 1.41(\mathrm{~d}, 3 \mathrm{H}, J 6.3$ $\left.\mathrm{Hz}, \mathrm{CH}_{3}\right), 1.82\left(\mathrm{~s}, 3 \mathrm{H}, \mathrm{CH}_{3}\right), 5.00(\mathrm{q}, 1 \mathrm{H}, J 6.3 \mathrm{~Hz}, \mathrm{CH}-\mathrm{O}), 7.00(\mathrm{~d}, 1 \mathrm{H}, J$ $8.4 \mathrm{~Hz}, \operatorname{ArH}), 7.11(\mathrm{~d}, 1 \mathrm{H}, J 8.4 \mathrm{~Hz}, \operatorname{ArH}), 7.18(\mathrm{~s}, 1 \mathrm{H}, \operatorname{ArH}), 7.21(\mathrm{t}, 1 \mathrm{H}, J$ $8.1 \mathrm{~Hz}, \mathrm{ArH}), 7.86\left(\mathrm{~s}, 1 \mathrm{H}, \mathrm{NH}_{2}\right), 8.27\left(\mathrm{~s}, 1 \mathrm{H}, \mathrm{NH}_{2}\right), 10.22(\mathrm{~s}, 1 \mathrm{H}, \mathrm{NH}) .{ }^{13} \mathrm{C}$ NMR (75.5 MHz, DMSO- $\left.d_{6}\right): \delta 11.0\left(\mathrm{CH}_{3}\right), 18.5\left(\mathrm{CH}_{3}\right), 76.6(\mathrm{CH}-\mathrm{O})$, 
$114.9(\mathrm{CH}, \mathrm{Ar}), 118.6(\mathrm{CH}, \mathrm{Ar}), 121.9(\mathrm{Ar}), 123.9(\mathrm{CH}, \mathrm{Ar}), 131.2(\mathrm{CH}$, Ar), $150.9(\mathrm{C}=\mathrm{N}), 158.2(\mathrm{C}-\mathrm{O}), 179.2(\mathrm{C}=\mathrm{S})$. HRESIMS: 315.962 $[\mathrm{M}+\mathrm{H}]^{+}$. Anal. Calcd. for $\mathrm{C}_{11} \mathrm{H}_{14} \mathrm{~N}_{3} \mathrm{OSBr}$ : C, 41.78; $\mathrm{H}, 4.46 ; \mathrm{N}, 13.29$. Found: C, 41.85; H, 4.12; N, 13.39 .

\subsubsection{2-(3-(4-Iodophenoxy)butan-2-ylidene)thiosemicarbazide (9o)}

Recrystallization in ethanol afforded yellowish crystals, yield $=83 \%$. M.p. $\left({ }^{\circ} \mathrm{C}\right): 154-156$. IR $(\mathrm{KBr}): 3347\left(\mathrm{NH}_{2}\right), 3243(\mathrm{NH})$, $1579(\mathrm{C}=\mathrm{N}) \mathrm{cm}^{-1} .{ }^{1} \mathrm{H}$ NMR $\left(400 \mathrm{MHz}\right.$, DMSO-d $\left.d_{6}\right): \delta 1.41(\mathrm{~d}, 3 \mathrm{H}, J 6.4$ $\left.\mathrm{Hz}, \mathrm{CH}_{3}\right), 1.81\left(\mathrm{~s}, 3 \mathrm{H}, \mathrm{CH}_{3}\right), 4.94(\mathrm{q}, 1 \mathrm{H}, J 6.4 \mathrm{~Hz}, \mathrm{CH}-\mathrm{O}), 6.83(\mathrm{~d}, 2 \mathrm{H}, J$ $8.4 \mathrm{~Hz}, \mathrm{CH}, \mathrm{ArH}$ ), 7.55 (d, 2H, J $8.4 \mathrm{~Hz}, 2 \mathrm{CH}, \operatorname{ArH}), 7.81$ (s, 1H, $\mathrm{NH}_{2}$ ), $8.24\left(\mathrm{~s}, 1 \mathrm{H}, \mathrm{NH}_{2}\right), 10.18(\mathrm{~s}, 1 \mathrm{H}, \mathrm{NH}) .{ }^{13} \mathrm{C} \mathrm{NMR}\left(75.5 \mathrm{MHz}, \mathrm{DMSO}-d_{6}\right)$ : $\delta 11.0\left(\mathrm{CH}_{3}\right), 18.6\left(\mathrm{CH}_{3}\right), 76.3(\mathrm{CH}-\mathrm{O}), 83.8(\mathrm{Ar}), 118.4(\mathrm{CH}, \mathrm{Ar}), 137.9$ $(\mathrm{CH}, \mathrm{Ar}), 151.2(\mathrm{C}=\mathrm{N}), 157.1(\mathrm{C}-\mathrm{O}), 179.1(\mathrm{C}=\mathrm{S})$. HRESIMS: 364.0118 $[\mathrm{M}]^{+}$. Anal. Calcd. for $\mathrm{C}_{11} \mathrm{H}_{14} \mathrm{~N}_{3} \mathrm{OSI}$ : C, 36.37; $\mathrm{H}, 3.89 ; \mathrm{N}, 11.57$. Found: C, 36.45; H, 3.65; N, 11.65.

\subsubsection{2-(3-([1,1'-Biphenyl]-4-yloxy)butan-2-ylidene) thiosemicarbazide $(\mathbf{9 p})$}

Recrystallization in ethanol afforded white crystals, yield $=91 \%$. M.p. $\left({ }^{\circ} \mathrm{C}\right): 164-166$. IR $(\mathrm{KBr}): 3404\left(\mathrm{NH}_{2}\right), 3236(\mathrm{~N}-\mathrm{H})$, $1592(\mathrm{C}=\mathrm{N}) \mathrm{cm}^{-1} .{ }^{1} \mathrm{H}$ NMR $\left(400 \mathrm{MHz}, \mathrm{DMSO}-d_{6}\right): \delta 1.46(\mathrm{~d}, 3 \mathrm{H}, J$ $\left.6 \mathrm{~Hz}, \mathrm{CH}_{3}\right), 1.87\left(\mathrm{~s}, 3 \mathrm{H}, \mathrm{CH}_{3}\right), 5.04(\mathrm{q}, 1 \mathrm{H}, J 6 \mathrm{~Hz}, \mathrm{CH}-\mathrm{O}), 7.09$ (d, 2H, J $9 \mathrm{~Hz}, \mathrm{ArH}), 7.20-7.47$ (m, 1H, ArH), 7.49-7.73 (m, 2H, ArH), 7.78$7.99(\mathrm{~m}, 4 \mathrm{H}, \mathrm{ArH}), 7.89\left(\mathrm{~s}, 1 \mathrm{H}, \mathrm{NH}_{2}\right), 8.30\left(\mathrm{~s}, 1 \mathrm{H}, \mathrm{NH}_{2}\right), 10.24(\mathrm{~s}, 1 \mathrm{H}$, $\mathrm{NH}) .{ }^{13} \mathrm{C}$ NMR (100 MHz, DMSO-d 6 ): $\delta 11.7\left(\mathrm{CH}_{3}\right), 19.5\left(\mathrm{CH}_{3}\right), 81.7$ (CH-O), 116.7 (CH, Ar), 126.9 (CH, Ar), $128.4(\mathrm{CH}, \mathrm{Ar}), 129.1(\mathrm{CH}, \mathrm{Ar})$, $129.5(\mathrm{CH}, \mathrm{Ar}), 133.6(\mathrm{CH}, \mathrm{Ar}), 140.4(\mathrm{C}, \mathrm{Ar}), 152.4(\mathrm{C}=\mathrm{N}), 157.6(\mathrm{C}-$ O), $179.8(\mathrm{C}=\mathrm{S})$. HRESIMS: $314.1336[\mathrm{M}+\mathrm{H}]^{+}$. Anal. Calcd. for $\mathrm{C}_{17} \mathrm{H}_{19} \mathrm{~N}_{3} \mathrm{OS}$ : C, 65.15; H, 6.11; N, 13.41. Found: C, 64.93; H, 5.77; N, 13.70 .

\subsubsection{2-(3-([1,1'-Biphenyl]-3-yloxy)butan-2-ylidene) thiosemicarbazide $(\mathbf{9 q})$}

Recrystallization in ethanol afforded white crystals, yield $=79 \%$. M.p. $\left({ }^{\circ} \mathrm{C}\right): 138-140 . \mathrm{IR}(\mathrm{KBr}): 3437\left(\mathrm{NH}_{2}\right), 3324(\mathrm{~N}-\mathrm{H})$, $1586(\mathrm{C}=\mathrm{N}) \mathrm{cm}^{-1}$. ${ }^{1} \mathrm{H}$ NMR $\left(400 \mathrm{MHz}, \mathrm{DMSO}-d_{6}\right): \delta 1.45(\mathrm{~d}, 3 \mathrm{H}, J 8.8$ $\left.\mathrm{Hz}, \mathrm{CH}_{3}\right), 1.85\left(\mathrm{~s}, 3 \mathrm{H}, \mathrm{CH}_{3}\right), 5.09$ (q, $\left.1 \mathrm{H}, \mathrm{J} 8.8 \mathrm{~Hz}, \mathrm{CH}-\mathrm{O}\right), 6.96$ (d, $1 \mathrm{H}$, ArH), 7.20-7.26 (m, 2H, ArH), 7.31-7.37 (m, 1H, ArH), 7.45 (t, 2H, $\mathrm{ArH}), 7.62(\mathrm{~d}, 2 \mathrm{H}, \mathrm{ArH}), 7.90\left(\mathrm{~s}, 1 \mathrm{H}, \mathrm{NH}_{2}\right), 8.26\left(\mathrm{~s}, 1 \mathrm{H}, \mathrm{NH}_{2}\right), 10.20(\mathrm{~s}$, $1 \mathrm{H}, \mathrm{NH}) .{ }^{13} \mathrm{C}$ NMR $\left(100 \mathrm{MHz}, \mathrm{DMSO}-d_{6}\right): \delta 11.0\left(\mathrm{CH}_{3}\right), 18.8\left(\mathrm{CH}_{3}\right)$, $76.4(\mathrm{CH}-\mathrm{O}), 113.9(\mathrm{CH}, \mathrm{Ar}), 114.8(\mathrm{CH}, \mathrm{Ar}), 119.4(\mathrm{CH}, \mathrm{Ar}), 126.7(\mathrm{CH}$, Ar), 127.6 (CH, Ar), 128.9 (CH, Ar), 130.0 (CH, Ar), 139.8 (C, Ar), 141.6 (C, Ar), $151.7(\mathrm{C}=\mathrm{N}), 157.8(\mathrm{C}-\mathrm{O}), 179.3(\mathrm{C}=\mathrm{S})$. HRESIMS: 314.1422 $[\mathrm{M}+\mathrm{H}]^{+}$. Anal. Calcd. for $\mathrm{C}_{17} \mathrm{H}_{19} \mathrm{~N}_{3} \mathrm{OS}$ : C, 65.15; $\mathrm{H}, 6.11$; N, 13.41 . Found: C, 65.17; H, 6.11; N, 13.86 .

\subsubsection{2-(3-([1,1'-Biphenyl]-2-yloxy)butan-2-ylidene)}

thiosemicarbazide (9r)

Recrystallization in ethanol afforded white crystals, yield $=83 \%$. M.p. $\left({ }^{\circ} \mathrm{C}\right): 179-181 . \mathrm{IR}(\mathrm{KBr}): 3416\left(\mathrm{NH}_{2}\right), 3226(\mathrm{~N}-\mathrm{H})$, $1596(\mathrm{C}=\mathrm{N}) \mathrm{cm}^{-1}$. ${ }^{1} \mathrm{H}$ NMR $\left(400 \mathrm{MHz}\right.$, DMSO-d $\left.d_{6}\right): \delta 1.32(\mathrm{~d}, 3 \mathrm{H}, J 6.0$ $\left.\mathrm{Hz}, \mathrm{CH}_{3}\right), 1.76\left(\mathrm{~s}, 3 \mathrm{H}, \mathrm{CH}_{3}\right), 4.97(\mathrm{q}, 1 \mathrm{H}, J 6.4 \mathrm{~Hz}, \mathrm{CH}-\mathrm{O}), 7.02(\mathrm{t}, 1 \mathrm{H}, J$ $7.6 \mathrm{~Hz}, \mathrm{ArH}), 7.14$ (d, 2H, J 8.4 Hz, ArH), 7.25-7.34 (m, 3H, ArH), 7.41 $(\mathrm{t}, 2 \mathrm{H}, J 7.2 \mathrm{~Hz}, \mathrm{ArH}), 7.49$ (d, $2 \mathrm{H}, J 7.2 \mathrm{~Hz}, \mathrm{ArH}), 7.73\left(\mathrm{~s}, 1 \mathrm{H}, \mathrm{NH}_{2}\right), 8.22$ $\left(\mathrm{s}, 1 \mathrm{H}, \mathrm{NH}_{2}\right), 10.16(\mathrm{~s}, 1 \mathrm{H}, \mathrm{NH}) .{ }^{13} \mathrm{C}$ NMR and DEPT (100 MHz, DMSO$\left.d_{6}\right): \delta 11.7\left(\mathrm{CH}_{3}\right), 19.0\left(\mathrm{CH}_{3}\right), 77.2(\mathrm{CH}-\mathrm{O}), 114.8(\mathrm{CH}, \mathrm{Ar}), 121.8(\mathrm{CH}$, $\mathrm{Ar}), 127.3(\mathrm{CH}, \mathrm{Ar}), 128.4(\mathrm{CH}, \mathrm{Ar}), 129.2(\mathrm{CH}, \mathrm{Ar}), 129.7(\mathrm{CH}, \mathrm{Ar})$, 130.9 (C, Ar), 131.1 (CH, Ar), $138.6(\mathrm{C}, \mathrm{Ar}), 152.2(\mathrm{C}-\mathrm{O}), 154.4(\mathrm{C}=\mathrm{N})$, $179.6(\mathrm{C}=\mathrm{S})$. HRESIMS: $314.1336[\mathrm{M}+\mathrm{H}]^{+}$. Anal. Calcd. for $\mathrm{C}_{17} \mathrm{H}_{19} \mathrm{~N}_{3} \mathrm{OS}$ : C, 65.15; H, 6.11; N, 13.41. Found: C, 65.70; H, 5.44; $\mathrm{N}$, 13.67.

\subsubsection{2-(3-(4-Phenoxyphenoxy)butan-2-ylidene)}

thiosemicarbazide (9s)

Recrystallization in ethanol afforded yellow crystals, yield $=71 \%$. M.p. $\left({ }^{\circ} \mathrm{C}\right): 111-112$. IR $(\mathrm{KBr}): 3423\left(\mathrm{NH}_{2}\right), 3238(\mathrm{~N}-\mathrm{H})$, $1593(\mathrm{C}=\mathrm{N}) \mathrm{cm}^{-1} .{ }^{1} \mathrm{H}$ NMR $(300 \mathrm{MHz}$, DMSO-d 6$): \delta 1.42(\mathrm{~d}, 3 \mathrm{H}, J$ $\left.6 \mathrm{~Hz}, \mathrm{CH}_{3}\right), 1.86\left(\mathrm{~s}, 3 \mathrm{H}, \mathrm{CH}_{3}\right), 4.93$ (q, $\left.1 \mathrm{H}, J 6 \mathrm{~Hz}, \mathrm{CH}-\mathrm{O}\right), 6.90-6.95$ (m, 4H, ArH), 7.00-7.05 (m, 3H, ArH), 7.32-7.38 (m, 2H, ArH), 7.81 $\left(\mathrm{s}, 1 \mathrm{H}, \mathrm{NH}_{2}\right), 8.26\left(\mathrm{~s}, 1 \mathrm{H}, \mathrm{NH}_{2}\right), 10.20(\mathrm{~s}, 1 \mathrm{H}, \mathrm{NH}) .{ }^{13} \mathrm{C} \mathrm{NMR}(75.5 \mathrm{MHz}$, DMSO-d $\left.d_{6}\right): \delta 11.8\left(\mathrm{CH}_{3}\right), 19.5\left(\mathrm{CH}_{3}\right), 77.3(\mathrm{CH}-\mathrm{O}), 117.6(\mathrm{CH}, \mathrm{Ar}), 118.2$ $(\mathrm{CH}, \mathrm{Ar}), 121.0(\mathrm{CH}, \mathrm{Ar}), 123.4(\mathrm{CH}, \mathrm{Ar}), 130.6(\mathrm{CH}, \mathrm{Ar}), 133.6(\mathrm{CH}, \mathrm{Ar})$, $150.5(\mathrm{C}-\mathrm{O}, \mathrm{Ar}), 152.5(\mathrm{C}=\mathrm{N}), 154.2(\mathrm{C}-\mathrm{O}, \mathrm{Ar}), 158.3(\mathrm{C}-\mathrm{O}), 179.8$ $(\mathrm{C}=\mathrm{S})$. HRESIMS: $330.0697[\mathrm{M}+\mathrm{H}]^{+}$. Anal. Calcd. for $\mathrm{C}_{17} \mathrm{H}_{19} \mathrm{~N}_{3} \mathrm{O}_{2} \mathrm{~S}$ : C, 61.98; H, 5.81; N, 12.76. Found: C, 61.83; H, 5.90; N, 12.95 .

\subsubsection{2-(3-(Naphthalen-1-yloxy)butan-2-ylidene)}

thiosemicarbazide (9t)

Recrystallization in ethanol afforded white crystals, yield $=98 \%$. M.p. $\left({ }^{\circ} \mathrm{C}\right): 158-160 . \mathrm{IR}(\mathrm{KBr}): 3408\left(\mathrm{NH}_{2}\right), 3228(\mathrm{~N}-\mathrm{H})$, $1597(\mathrm{C}=\mathrm{N}) \mathrm{cm}^{-1} .{ }^{1} \mathrm{H}$ NMR $\left(300 \mathrm{MHz}, \mathrm{DMSO}-d_{6}\right): \delta 1.56(\mathrm{~d}, 3 \mathrm{H}, J 6.8$ $\left.\mathrm{Hz}, \mathrm{CH}_{3}\right), 1.86$ (s, 3H, CH 3 ), 5.18 (q, 1H, J 6.4 Hz, CH-O), 7.05 (d, 1H, J $8 \mathrm{~Hz}, \mathrm{ArH}), 7.36$ (t, $1 \mathrm{H}, J$ 7.6 Hz, ArH), 7.45-7.53 (m, 3H, ArH), 7.84$7.86(\mathrm{~m}, 1 \mathrm{H}, \mathrm{ArH}), 7.88\left(\mathrm{~s}, 1 \mathrm{H}, \mathrm{NH}_{2}\right), 8.19-8.22(\mathrm{~m}, 1 \mathrm{H}, \mathrm{ArH}), 8.26(\mathrm{~s}$, $\left.1 \mathrm{H}, \mathrm{NH}_{2}\right), 10.20(\mathrm{~s}, 1 \mathrm{H}, \mathrm{NH}) .{ }^{13} \mathrm{C}$ NMR $\left(75.5 \mathrm{MHz}\right.$, DMSO-d $\left.d_{6}\right): \delta 10.4$ $\left(\mathrm{CH}_{3}\right), 18.3\left(\mathrm{CH}_{3}\right), 76.0(\mathrm{CH}-\mathrm{O}), 106.6(\mathrm{CH}, \mathrm{Ar}), 119.8(\mathrm{CH}, \mathrm{Ar}), 121.0$ (CH, Ar), $124.7(\mathrm{CH}, \mathrm{Ar}), 124.9(\mathrm{CH}, \mathrm{Ar}), 125.6(\mathrm{CH}, \mathrm{Ar}), 125.9(\mathrm{CH}, \mathrm{Ar})$, 127.0 (CH, Ar), $133.6(\mathrm{CH}, \mathrm{Ar}), 151.3(\mathrm{C}=\mathrm{N}), 152.0(\mathrm{C}-\mathrm{O}, \mathrm{Ar}), 179.7$ $(\mathrm{C}=\mathrm{S})$. HRESIMS: $288.1283[\mathrm{M}+\mathrm{H}]^{+}$. Anal. Calcd. for $\mathrm{C}_{15} \mathrm{H}_{17} \mathrm{~N}_{3} \mathrm{OS}: \mathrm{C}$, 62.69; H, 5.96; N, 14.62. Found: C, 62.63; H, 6.07; N, 14.92.

\subsubsection{2-(3-(Naphthalen-2-yloxy)butan-2-ylidene)}

thiosemicarbazide $(\mathbf{9 u})$

Recrystallization in ethanol afforded white crystals, yield $=89 \%$. M.p. $\left({ }^{\circ} \mathrm{C}\right): 150-152 . \mathrm{IR}(\mathrm{KBr}): 3341\left(\mathrm{NH}_{2}\right), 3270(\mathrm{~N}-\mathrm{H})$, $1614(\mathrm{C}=\mathrm{N}) \mathrm{cm}^{-1} .{ }^{1} \mathrm{H}$ NMR $\left(400 \mathrm{MHz}, \mathrm{DMSO}-d_{6}\right): \delta 1.49(\mathrm{~d}, 3 \mathrm{H}, J 6.4$ $\mathrm{Hz}, \mathrm{CH}_{3}$ ), 1.85 (s, 3H, $\mathrm{CH}_{3}$ ), 5.13 (q, 1H, J $6.3 \mathrm{~Hz}, \mathrm{CH}-\mathrm{O}$ ), 7.19 (d, $1 \mathrm{H}, J$ $9.2 \mathrm{~Hz}, \mathrm{ArH}), 7.19$ (d, 1H, J 9.2 Hz, ArH), 7.33 (t, 1H, J 7.6 Hz, ArH), 7.41-7.46 (m, 2H, ArH), 7.74 (d, 1H, J $8.4 \mathrm{~Hz}, \operatorname{ArH}), 7.80$ (d, 1H, $8.8 \mathrm{~Hz}, \mathrm{ArH}), 7.98\left(\mathrm{~s}, 1 \mathrm{H}, \mathrm{NH}_{2}\right), 8.27\left(\mathrm{~s}, 1 \mathrm{H}, \mathrm{NH}_{2}\right), 10.20(\mathrm{~s}, 1 \mathrm{H}, \mathrm{NH}) .{ }^{13} \mathrm{C}$ NMR (100 MHz, DMSO- $\left.d_{6}\right): \delta 10.9\left(\mathrm{CH}_{3}\right), 18.6\left(\mathrm{CH}_{3}\right), 76.2(\mathrm{CH}-\mathrm{O})$, 108.9 (CH, Ar), 118.9 (CH, Ar), 123.7 (CH, Ar), 126.3 (CH, Ar), 126.7 (CH, Ar), 127.4 (CH, Ar), 128.5 (CH, Ar), 129.3 (CH, Ar), $134.0(\mathrm{CH}, \mathrm{Ar})$, $151.6(\mathrm{C}=\mathrm{N}), 154.9(\mathrm{C}-\mathrm{O}, \mathrm{Ar}), 179.2(\mathrm{C}=\mathrm{S})$. HRESIMS: 288.1283 $[\mathrm{M}+\mathrm{H}]^{+}$. Anal. Calcd. for $\mathrm{C}_{15} \mathrm{H}_{17} \mathrm{~N}_{3} \mathrm{OS}: \mathrm{C}, 62.69 ; \mathrm{H}, 5.96 ; \mathrm{N}, 14.62$. Found: C, 62.78; H, 6.01; N, 14.97.

\subsubsection{2-(3-(3,4-Dichlorophenoxy)butan-2-ylidene)} thiosemicarbazide $(\mathbf{9 v})$

Recrystallization in ethanol afforded white crystals, yield $=74 \%$. M.p. $\left({ }^{\circ} \mathrm{C}\right): 154-156 . \mathrm{IR}(\mathrm{KBr}): 3420\left(\mathrm{NH}_{2}\right), 3259(\mathrm{~N}-\mathrm{H})$, $1593(\mathrm{C}=\mathrm{N}) \mathrm{cm}^{-1} .{ }^{1} \mathrm{H}$ NMR $\left(300 \mathrm{MHz}, \mathrm{DMSO}-d_{6}\right): \delta 1.42(\mathrm{~d}, J 6.6 \mathrm{~Hz}$, $\left.3 \mathrm{H}, \mathrm{CH}_{3}\right), 1.82\left(\mathrm{~s}, 3 \mathrm{H}, \mathrm{CH}_{3}\right), 5.00(\mathrm{q}, 1 \mathrm{H}, J 6.6 \mathrm{~Hz}, \mathrm{CH}-\mathrm{O}), 7.00$ (dd, $1 \mathrm{H}$, J $\left.9.0 \mathrm{~Hz},{ }^{4} J 3.0 \mathrm{~Hz}, \mathrm{ArH}\right), 7.27$ (d, 1H, $\left.{ }^{4} J 3.0 \mathrm{~Hz}, \mathrm{ArH}\right), 7.47$ (d, $1 \mathrm{H}, J$ $9.0 \mathrm{~Hz}, \mathrm{ArH}$ ), 7.85 (broad s, $1 \mathrm{H}, \mathrm{NH}_{2}$ ), 8.24 (broad s, $1 \mathrm{H}, \mathrm{NH}_{2}$ ), 10.19 $(\mathrm{s}, 1 \mathrm{H}, \mathrm{NH}) .{ }^{13} \mathrm{C}$ NMR $\left(75.5 \mathrm{MHz}, \mathrm{DMSO}-d_{6}\right): \delta 11.0\left(\mathrm{CH}_{3}\right), 18.4\left(\mathrm{CH}_{3}\right)$, 77.1 ( $\mathrm{CH}-\mathrm{O}), 116.5$ ( $\mathrm{CH}, \mathrm{Ar}), 117.7(\mathrm{CH}, \mathrm{Ar}), 122.9(\mathrm{C}-\mathrm{Cl}, \mathrm{Ar}), 130.9$ (CH, Ar), $131.5(\mathrm{Ar}), 150.5(\mathrm{C}=\mathrm{N}), 156.7(\mathrm{C}-\mathrm{O}), 179.3(\mathrm{C}=\mathrm{S})$. HRESIMS: $306.0320[\mathrm{M}+\mathrm{H}]^{+}$. Anal. Calcd. for $\mathrm{C}_{11} \mathrm{H}_{13} \mathrm{~N}_{3} \mathrm{OSCl}_{2}$ : C, 43.15; H, 4.28; N, 13.72. Found: C, 43.39; H, 4.09; N, 13.69.

\subsubsection{2-(3-(3-Chloro-4-fluorophenoxy)butan-2-ylidene) thiosemicarbazide $(\mathbf{9 w})$}

Recrystallization in ethanol afforded yellowish crystals, yield $=91 \%$. M.p. $\left({ }^{\circ} \mathrm{C}\right): 134-136 . \mathrm{IR}(\mathrm{KBr}): 3423\left(\mathrm{NH}_{2}\right), 3236(\mathrm{NH})$, $1579(\mathrm{C}=\mathrm{N}) \mathrm{cm}^{-1}$. ${ }^{1} \mathrm{H}$ NMR $\left(300 \mathrm{MHz}, \mathrm{DMSO}-d_{6}\right): \delta 1.41(\mathrm{~d}, 3 \mathrm{H}, J 6.4$ $\left.\mathrm{Hz}, \mathrm{CH}_{3}\right), 1.82\left(\mathrm{~s}, 3 \mathrm{H}, \mathrm{CH}_{3}\right), 4.96(\mathrm{q}, 1 \mathrm{H}, \mathrm{J} 6.4 \mathrm{~Hz}, \mathrm{CH}-\mathrm{O}), 6.97-7.01$ 
(m, 1H, ArH), 7.20-7.22 (m, 1H, ArH), $7.28(\mathrm{t}, 1 \mathrm{H}, J 9.2 \mathrm{~Hz}, \mathrm{ArH}), 7.88$ $\left(\mathrm{s}, 1 \mathrm{H}, \mathrm{NH}_{2}\right), 8.26\left(\mathrm{~s}, 1 \mathrm{H}, \mathrm{NH}_{2}\right), 10.21(\mathrm{~s}, 1 \mathrm{H}, \mathrm{NH}) .{ }^{13} \mathrm{C} \mathrm{NMR}(100 \mathrm{MHz}$, DMSO-d $\left.d_{6}\right): \delta 11.0\left(\mathrm{CH}_{3}\right), 18.5\left(\mathrm{CH}_{3}\right), 77.1(\mathrm{CH}-\mathrm{O}), 116.0(\mathrm{CH}, \mathrm{Ar}), 117.0$ $(\mathrm{CH}, \mathrm{Ar}), 117.4(\mathrm{CH}, \mathrm{Ar}), 119.7(\mathrm{Ar}), 150.7$ (C-F, Ar), $153.1(\mathrm{C}-\mathrm{O}), 153.8$ $(\mathrm{C}=\mathrm{N}), 179.2(\mathrm{C}=\mathrm{S})$. HRESIMS: $290.0551[\mathrm{M}+\mathrm{H}]^{+}$. Anal. Calcd. for $\mathrm{C}_{11} \mathrm{H}_{13} \mathrm{~N}_{3}$ OSFCl: $\mathrm{C}, 45.60 ; \mathrm{H}, 4.52 ; \mathrm{N}, 14.50$. Found: C, 45.35; H, 4.49; $\mathrm{N}, 14.42$.

\subsubsection{2-(3-(2,3-Dichlorophenoxy)butan-2-ylidene)} thiosemicarbazide $(\mathbf{9 x})$

Recrystallization in ethanol afforded yellowish crystals, yield $=55 \%$. M.p. $\left({ }^{\circ} \mathrm{C}\right): 132-134$. IR $(\mathrm{KBr}): 3423\left(\mathrm{NH}_{2}\right), 3236(\mathrm{NH})$, $1507(\mathrm{C}=\mathrm{N}) \mathrm{cm}^{-1}$. ${ }^{1} \mathrm{H}$ NMR $\left.(300 \mathrm{MHz} \text {, DMSO-d })_{6}\right): \delta 1.47(\mathrm{~d}, 3 \mathrm{H}, J 6.0$ $\left.\mathrm{Hz}, \mathrm{CH}_{3}\right), 1.85\left(\mathrm{~s}, 3 \mathrm{H}, \mathrm{CH}_{3}\right), 5.09(\mathrm{q}, 1 \mathrm{H}, J 6.0 \mathrm{~Hz}, \mathrm{CH}-\mathrm{O}), 7.18-7.27(\mathrm{~m}$, $3 \mathrm{H}, \mathrm{ArH}), 7.84\left(\mathrm{~s}, 1 \mathrm{H}, \mathrm{NH}_{2}\right), 8.28\left(\mathrm{~s}, 1 \mathrm{H}, \mathrm{NH}_{2}\right), 10.23(\mathrm{~s}, 1 \mathrm{H}, \mathrm{NH}) .{ }^{13} \mathrm{C}$ NMR (100 MHz, DMSO- $\left.d_{6}\right): \delta 10.9\left(\mathrm{CH}_{3}\right), 18.5\left(\mathrm{CH}_{3}\right), 78.0(\mathrm{CH}-\mathrm{O})$, $114.1(\mathrm{CH}, \mathrm{Ar}), 120.6(\mathrm{CH}, \mathrm{Ar}), 122.5(\mathrm{Ar}), 128.3(\mathrm{CH}, \mathrm{Ar}), 132.3(\mathrm{Ar})$, $150.33(\mathrm{C}-\mathrm{O}, \mathrm{Ar}), 154.0(\mathrm{C}=\mathrm{N}), 179.2(\mathrm{C}=\mathrm{S})$. HRESIMS: 306.0235 $[\mathrm{M}+\mathrm{H}]^{+}$. Anal. Calcd. for $\mathrm{C}_{11} \mathrm{H}_{13} \mathrm{~N}_{3} \mathrm{OSCl}_{2}$ : C, 43.15; $\mathrm{H}, 4.28 ; \mathrm{N}, 13.72$. Found: C, 42.61; H, 3.99; N, 13.62 .

\subsection{Cells}

BALB/c mouse, housed in the Centro de Pesquisas Aggeu Magalhaes (Recife, Brazil), were used to collect splenocytes accordingly to a previously reported protocol [61]. T. cruzi Dm28c epimastigotes, cloned derived from Dm28 strain (TcI) [62], were maintained at $26{ }^{\circ} \mathrm{C}$ in LIT (Liver Infusion Tryptose) medium supplemented with $10 \%$ fetal bovine serum (FBS) (Life, Carlsbad, USA), 1\% hemin (Sigma-Aldrich, St. Louis, USA), 1\% R9 medium (SigmaAldrich, St. Louis, USA), and $50 \mu \mathrm{g} / \mathrm{mL}$ gentamycin (Novafarma, Anápolis, Brazil). Y strain (TcII) trypomastigotes were obtained from the supernatant of infected LLC-MK2 cells and were maintained in RPMI-1640 medium (Sigma-Aldrich, St. Louis, USA) supplemented with $10 \% \mathrm{FBS}$, and $50 \mu \mathrm{g} / \mathrm{mL}$ gentamycin at $37^{\circ} \mathrm{C}$ and $5 \% \mathrm{CO}_{2}$. Experiments were carried out in accordance with the recommendations of ethical issues guidelines and were approved by the local Animal Ethics Committee (number 0266/05).

\subsection{Host cell cytotoxicity}

BALB/c mouse splenocytes were seeded at $5 \times 10^{6}$ cells/well in 96-well plate. Compounds were dissolved in DMSO and then diluted in RPMI-1640 medium in a serial dilution (1.23, 3.7, 33.33 and $100 \mu \mathrm{g} / \mathrm{mL}$ ) and added to respective wells, in triplicate. The final DMSO concentration was $1 \%$. The plate was incubated for $24 \mathrm{~h}$ at $37{ }^{\circ} \mathrm{C}$ and $5 \% \mathrm{CO}_{2}$ containing $1.0 \mu \mathrm{Ci}$ of ${ }^{3} \mathrm{H}$-thymidine (PerkinElmer, Waltham, MA). Cells were harvested and then transferred to a liquid scintillation counter (WALLAC 1209, Rackbeta Pharmacia, Stockholm, Sweden) and the percent of ${ }^{3} \mathrm{H}$-thymidine incorporation was determined. The highest non-cytotoxic concentration (HNC) was determined for each compound. For determining the $\mathrm{CC}_{50}$ values, five different concentrations were used.

\subsection{Anti-T. cruzi activity (epimastigotes)}

Epimastigotes (Dm28c) in LIT media were counted in a hemocytometer and then seeded at $10^{6}$ cells/well into a 96-well plate. Compounds were dissolved in DMSO and then diluted in LIT medium in a serial dilution $(1.23,3.70,11.11,33.33$ and $100 \mu \mathrm{g} / \mathrm{mL})$ and added to respective wells, in triplicate. The final DMSO concentration in the plate was $1 \%$. Plate was incubated for 5 days at $26^{\circ} \mathrm{C}$, aliquots of each well were collected, and the number of viable parasites were counted in a Neubauer chamber and compared to untreated parasite culture. Inhibitory concentration for $50 \%$ ( $\left.\mathrm{IC}_{50}\right)$ was calculated using nonlinear regression on Prism 4.0 GraphPad software. Benznidazole and nifurtimox were used as the reference drugs.

\subsection{Anti-T. cruzi activity (trypomastigotes)}

Metacyclic trypomastigotes were collected from the supernatant of infected LLC-MK2 cells and then seeded at $4 \times 10^{5}$ cells/well in RPMI-1640 medium. All compounds were dissolved in DMSO and then diluted in RPMI-1640 medium in a serial dilution (1.23, $3.70,11.11,33.33$ and $100 \mu \mathrm{g} / \mathrm{mL}$ ) and added to respective wells, in triplicate. The final DMSO concentration was $1 \%$. Plate was incubated for $24 \mathrm{~h}$ at $37{ }^{\circ} \mathrm{C}$ and $5 \%$ of $\mathrm{CO}_{2}$. Aliquots of each well were collected, and the number of viable parasites was counted in a Neubauer chamber. The percentage of inhibition was calculated in relation to untreated cultures. Cytotoxic concentration for 50\% $\left(\mathrm{CC}_{50}\right)$ calculation was also carried out using nonlinear regression with Prism 4.0 GraphPad software. Benznidazole and nifurtimox were used as the reference drugs.

\subsection{Inhibition of catalytic activity of cruzain}

Recombinant cruzain was gently provided by Allison Doak and Dr. Brian Shoichet, from the University of California San Francisco. Cruzain activity was measured as previously described, by monitoring the cleavage of the fluorogenic substrate Z-Phe-Arg-aminomethylcoumarin (Z-FR-AMC) in a Synergy 2 (Biotek), from the Center of Flow Cytometry and Fluorimetry at the Biochemistry and Immunology Department (UFMG), using filters of $340 \mathrm{~nm}$ for excitation and $440 \mathrm{~nm}$ for emission. Assays were performed in sodium acetate $0.1 \mathrm{M} \mathrm{pH} 5.5$ and in the presence of $1 \mathrm{mM} \beta$-mercaptoethanol and $0.01 \%$ Triton X-100. The final concentration of cruzain was $0.5 \mathrm{nM}$, and the substrate concentration was $2.5 \mu \mathrm{M}$ $\left(K_{\mathrm{m}}=1.0 \mu \mathrm{M}\right)$. Compounds (9a, 9h, 9k, 9m, 9n, 9o and 9s) were screened at $100 \mu \mathrm{M}$, while $(\mathbf{9 g}, \mathbf{9 p}$ and $\mathbf{9 t})$ were tested at $50 \mu \mathrm{M}$. Screening was performed in two conditions, without preincubation with the enzyme and after a $10-$ min pre-incubation with enzyme. All compounds were assayed in two independent experiments, each performed in triplicates. Assays were followed for $5 \mathrm{~min}$, and activity was calculated based on a DMSO control.

\subsection{Flow cytometry analysis}

Trypomastigotes $\left(4 \times 10^{5}\right.$ cells $\left./ \mathrm{mL}\right)$ were resuspended in RPMI1640 medium and treated with compound $(9 r)(0.25$ and $1.1 \mu \mathrm{M})$ for $24 \mathrm{~h}$ at $37{ }^{\circ} \mathrm{C}$ with $5 \% \mathrm{CO}_{2}$. Parasites were labeled with propidium iodide (PI) and annexin V using the annexin V-FITC apoptosis detection kit (Ebioscience, San Diego, USA) according to the manufacturer instructions. Experiment was performed using a BD Calibur flow cytometer (San Jose, USA) by acquiring 50,000 events at least, and data were analyzed by BD CellQuest software (San Jose, USA). Two independent experiments, in triplicate, were performed.

\section{Acknowledgments}

This work was funded by CNPq (grant $471461 / 2011-3$ to A.C.L.L. and $477435 / 2012-2$ to R.S.F.) and FACEPE. A.C.L.L. and C.A.S. and V.R.A.P. are recipients of a CNPq fellowship, A.D.T.O. held a FACEPE scholarship and D.R.M.M. holds a FAPESB post-doctoral scholarship. Authors are thankful to the CPqGM Proteomic facility for determining mass spectral, Instituto de Física de São Carlos for allowing the use of the diffractometer and Centro de Citometria e Fluorimetria da UFMG/FAPEMIG for allowing the use of the fluorimeter. We are very thankful to Allison Doak and Dr. Brian Shoichet (University of California San Francisco) for providing recombinant cruzain. 
Crystallographic data for compound (9a) can be obtained free of charge from the Cambridge Crystallographic Data Centre (deposition number 945350, www.ccdc.cam.ac.uk/data_request/cif).

\section{References}

[1] A. Rassi Jr., A. Rassi, J.A. Marin-Neto, Chagas disease, Lancet 375 (2010) 1388 1402, http://dx.doi.org/10.1016/S0140-6736(10)60061-X.

[2] J.A. Urbina, New advances in the management of a long-neglected disease, Clinical Infectious Diseases 49 (2009) 1685-1687, http://dx.doi.org/10.1086/ 648073.

[3] F.S. Machado, L.A. Jelicks, L.V. Kirchhoff, J. Shirani, F. Nagajyothi, S. Mukherjee, R. Nelson, C.M. Coyle, D.C. Spray, A.C. de Carvalho, F. Guan, C.M. Prado, M.P. Lisanti, L.M. Weiss, S.P. Montgomery, H.B. Tanowitz, Chagas heart disease: report on recent developments, Cardiology in Review 20 (2012) 53-65, http://dx.doi.org/10.1097/CRD.0b013e31823efde2.

[4] M.J. Pinazo, J. Muñoz, E. Posada, P. López-Chejade, M. Gállego, E. Ayala, E. del Cacho, D. Soy, J. Gascon, Tolerance of benznidazole in treatment of Chagas' disease in adults, Antimicrobial Agents and Chemotherapy 54 (2010) 48964899, http://dx.doi.org/10.1128/AAC.00537-10.

[5] R.L. Tarleton, J.W. Curran, Is Chagas disease really the "New HIV/AIDS of the Americas"? PLOS Neglected Tropical Diseases 6 (2012) e1861, http:// dx.doi.org/10.1371/journal.pntd.0001861.

[6] F.S. Buckner, J.A. Urbina, Recent developments in sterol 14-demethylase inhibitors for Chagas disease, International Journal for Parasitology - Drugs and Drug Resistance 2 (2012) 236-242, http://dx.doi.org/10.1016/ j.ijpddr.2011.12.002.

[7] C.B. Lantwin, I. Schlichting, W. Kabsch, E.F. Pai, R.L. Krauth-Siegel, The structure of Trypanosoma cruzi trypanothione reductase in the oxidized and NADPH reduced state, Proteins 18 (1994) 161-173, http://dx.doi.org/10.1002/ prot.340180208.

[8] J.C. Engel, P.S. Doyle, I. Hsieh, J.H. McKerrow, Cysteine protease inhibitors cure an experimental Trypanosoma cruzi infection, Journal of Experimental Medicine 188 (1998) 725-734, http://dx.doi.org/10.1084/jem.188.4.725.

[9] S.S. Dc-Rubin, S. Schenkman, Trypanosoma cruzi trans-sialidase as a multifunctional enzyme in Chagas' disease, Cellular Microbiology 14 (2012) 15221530, http://dx.doi.org/10.1111/j.1462-5822.2012.01831.x.

[10] S.E. Wilkowsky, M.A. Barbieri, P. Stahl, E.L. Isola, Trypanosoma cruzi: phosphatidylinositol 3-kinase and protein kinase B activation is associated with parasite invasion, Experimental Cell Research 264 (2001) 211-218, http:// dx.doi.org/10.1006/excr.2000.5123.

[11] P.S. Doyle, Y.M. Zhou, J.C. Engel, J.H. McKerrow, A cysteine protease inhibitor cures Chagas' disease in an immunodeficient-mouse model of infection, Antimicrobial Agents and Chemotherapy 51 (2007) 3932-3939, http:// dx.doi.org/10.1128/AAC.00436-07.

[12] F. Villalta, M.C. Dobish, P.N. Nde, Y.Y. Kleshchenko, T.Y. Hargrove, C.A. Johnson, M.R. Waterman, J.N. Johnston, G.I. Lepesheva, VNI cures acute and chronic experimental Chagas disease, Journal of Infectious Diseases 208 (2013) 504511, http://dx.doi.org/10.1093/infdis/jit042.

[13] M.D. Soeiro, E.M. de Souza, C.F. da Silva, D.G.J. Batista, M.M. Batista, B.P. Pavão, J.S. Araújo, C.A. Aiub, P.B. da Silva, J. Lionel, C. Britto, K. Kim, G. Sulikowski, T.Y. Hargrove, M.R. Waterman, G.I. Lepesheva, In Vitro and in vivo studies of the antiparasitic activity of sterol $14 \alpha$-demethylase (CYP51) inhibitor VNI against drug-resistant strains of Trypanosoma cruzi, Antimicrobial Agents and Chemotherapy 57 (2013) 4151-4163, http://dx.doi.org/10.1128/AAC.00070 13.

[14] A.F. Francisco, P.M. de Abreu Vieira, J.M. Arantes, M.L. Pedrosa, H.R. Martins, M. Silva, V.M. Veloso, M. de Lana, M.T. Bahia, W.L. Tafuri, C.M. Carneiro, Trypanosoma cruzi: desferrioxamine decreases mortality and parasitemia in infected mice through a trypanostatic effect, Experimental Parasitology 120 (2008) 314-319, http://dx.doi.org/10.1016/j.exppara.2011.05.011.

[15] S. Cencig, N. Coltel, C. Truyens, Y. Carlier, Evaluation of benznidazole treatment combined with nifurtimox, posaconazole or AmBisome ${ }^{\circledR}$ in mice infected with Trypanosoma cruzi strains, International Journal of Antimicrobial Agents $40 \quad$ (2012) 527-532, http://dx.doi.org/10.1016/ j.ijantimicag.2012.08.002.

[16] D.R.M. Moreira, A.C.L. Leite, R.R. dos Santos, M.B.P. Soares, Approaches for the development of new anti-Trypanosoma cruzi agents, Current Drug Targets 10 (2009) 212-231, http://dx.doi.org/10.2174/138945009787581140.

[17] A.A. Rascón Jr., J.H. McKerrow, Synthetic and natural protease inhibitors provide insights into parasite development, virulence and pathogenesis Current Medicinal Chemistry 20 (2013) 3078-3102, http://dx.doi.org/ $10.2174 / 0929867311320250005$.

[18] V.G. Duschak, M. Ciaccio, J.R. Nassert, M.A. Basombrio, Enzymatic activity, protein expression and gene sequence of cruzipain in virulent and attenuated Trypanosoma cruzi strains, Journal of Parasitology 87 (2001) 1016-1022.

[19] P.S. Doyle, Y.M. Zhou, I. Hsieh, D.C. Greenbaum, J.H. McKerrow, J.C. Engel, The Trypanosoma cruzi protease cruzain mediates immune evasion, Plos Pathogens 7 (2011) e1002139, http://dx.doi.org/10.1371/journal.ppat.1002139.

[20] X. Du, E. Hansell, J.C. Engel, C.R. Caffrey, F.E. Cohen, J.H. McKerrow, Aryl ureas represent a new class of anti-trypanosomal agents, Chemistry \& Biology 7 (2000) 733-742, http://dx.doi.org/10.1016/S1074-5521(00)00018-1.
[21] H.J. Wiggers, J.R. Rocha, W.B. Fernandes, R. Sesti-Costa, Z.A. Carneiro, J. Cheleski, A.B. da Silva, L. Juliano, M.H. Cezari, J.S. Silva, J.H. McKerrow, C.A. Montanari, Non-peptidic cruzain inhibitors with trypanocidal activity discovered by virtual screening and in vitro assay, PLOS Neglected Tropical Diseases 7 (2013) e2370, http://dx.doi.org/10.1371/journal.pntd.0002370.

[22] J.M. dos Santos Filho, A.C.L. Leite, B.G. de Oliveira, D.R.M. Moreira, M.S. Lima, M.B.P. Soares, L.F.C. Leite, Design, synthesis and cruzain docking of 3-(4substituted-aryl)-1,2,4-oxadiazole- $N$-acylhydrazones as anti-Trypanosoma cruzi agents, Bioorganic \& Medicinal Chemistry 17 (2009) 6682-6691, http:// dx.doi.org/10.1016/j.bmc.2009.07.068.

[23] N.C. Romeiro, G. Aguirre, P. Hernández, M. González, H. Cerecetto, I. Aldana, S. Pérez-Silanes, A. Monge, E.J. Barreiro, L.M. Lima, Synthesis, trypanocidal activity and docking studies of novel quinoxaline- $N$-acylhydrazones, designed as cruzain inhibitors candidates, Bioorganic \& Medicinal Chemistry 17 (2009) 641-652, http://dx.doi.org/10.1016/j.bmc.2008.11.065.

[24] J.M. dos Santos-Filho, D.R. Moreira, C.A. de Simone, R.S. Ferreira, J.H. McKerrow, C.S. Meira, E.T. Guimarães, M.B.P. Soares, Optimization of antiTrypanosoma cruzi oxadiazoles leads to identification of compounds with efficacy in infected mice, Bioorganic \& Medicinal Chemistry 20 (2012) 64236433, http://dx.doi.org/10.1016/j.bmc.2012.08.047.

[25] T.N. Franklim, L. Freire-de-Lima, J.N.S. Diniz, J.O. Previato, R.N. Castro, L. Mendonça-Previato, M.E.F. de Lima, Design, synthesis and trypanocidal evaluation of novel 1,2,4-triazoles-3-thiones derived from natural piperine, Molecules $18 \quad$ (2013) 6366-6382, http://dx.doi.org/10.3390/ molecules18066366.

[26] K. Brak, P.S. Doyle, J.H. McKerrow, J.A. Ellman, Identification of a new class of nonpeptidic inhibitors of cruzain, Journal of the American Chemical Society 130 (2008) 6404-6410, http://dx.doi.org/10.1021/ja710254m.

[27] K. Brak, I.D. Kerr, K.T. Barrett, N. Fuchi, M. Debnath, K. Ang, J.C. Engel, J.H. McKerrow, P.S. Doyle, L.S. Brinen, J.A. Ellman, Nonpeptidic tetrafluorophenoxymethyl ketone cruzain inhibitors as promising new leads for Chagas disease chemotherapy, Journal of Medicinal Chemistry 53 (2010) 1763-1773, http://dx.doi.org/10.1021/jm901633v.

[28] X. Du, C. Guo, E. Hansell, P.S. Doyle, C.R. Caffrey, T.P. Holler, J.H. McKerrow, F.E. Cohen, Synthesis and structure-activity relationship study of potent trypanocidal thio semicarbazone inhibitors of the trypanosomal cysteine protease cruzain, Journal of Medicinal Chemistry 45 (2002) 2695-2707, http:// dx.doi.org/10.1021/jm010459j.

[29] D.C. Greenbaum, Z. Mackey, E. Hansell, P. Doyle, J. Gut, C.R. Caffrey, J. Lehrman, P.J. Rosenthal, J.H. McKerrow, K. Chibale, Synthesis and structure-activity relationships of parasiticidal thiosemicarbazone cysteine protease inhibitors against Plasmodium falciparum, Trypanosoma brucei, and Trypanosoma cruzi, Journal of Medicinal Chemistry 47 (2004) 3212-3219, http://dx.doi.org/ 10.1021/jm030549j.

[30] R. Siles, S.E. Chen, M. Zhou, K.G. Pinney, M.L. Trawick, Design, synthesis, and biochemical evaluation of novel cruzain inhibitors with potential application in the treatment of Chagas' disease, Bioorganic \& Medicinal Chemistry Letters 16 (2006) 4405-4409, http://dx.doi.org/10.1016/j.bmcl.2006.05.041.

[31] N.B. Lozano, V.G. Maltarollo, K.C. Weber, K.M. Honorio, R.V. Guido, A.D. Andricopulo, A.B. Da Silva, Molecular features for antitrypanosomal activity of thiosemicarbazones revealed by OPS-PLS QSAR studies, Medicinal Chemistry 8 (2012) 1045-1056.

[32] W. Porcal, P. Hernández, L. Boiani, M. Boiani, A. Ferreira, A. Chidichimo, J.J. Cazzulo, C. Olea-Azar, M. González, H. Cerecetto, New trypanocidal hybrid compounds from the association of hydrazone moieties and benzofuroxan heterocycle, Bioorganic \& Medicinal Chemistry 16 (2008) 6995-7004, http:// dx.doi.org/10.1016/j.bmc.2008.05.038.

[33] M. Vieites, L. Otero, D. Santos, C. Olea-Azar, E. Norambuena, G. Aguirre, H. Cerecetto, M. González, U. Kemmerling, A. Morello, J. Diego Maya, D. Gambino, Risedronate metal complexes potentially active against Chagas disease, Journal of Inorganic Biochemistry 103 (2009) 411-418, http:// dx.doi.org/10.1016/j.jinorgbio.2010.08.004.

[34] G.H. Trossini, A. Malvezzi, A.T. Amaral, C.O. Rangel-Yagui, M.A. Izidoro, M.H. Cezari, L. Juliano, C.M. Chin, C.M. Menezes, E.I. Ferreira, Cruzain inhibition by hydroxymethylnitrofurazone and nitrofurazone: investigation of a new target in Trypanosoma cruzi, Journal of Enzyme Inhibition and Medicinal Chemistry 25 (2010) 62-67, http://dx.doi.org/10.3109/14756360902941058.

[35] M.E. Caputto, L.E. Fabian, D. Benítez, A. Merlino, N. Ríos, H. Cerecetto, G.Y. Moltrasio, A.G. Moglioni, M. González, L.M. Finkielsztein, Thiosemicarbazones derived from 1-indanones as new anti-Trypanosoma cruzi agents, Bioorganic \& Medicinal Chemistry 19 (2011) 6818-6826, http:// dx.doi.org/10.1016/j.bmc.2011.09.037.

[36] B. Demoro, C. Sarniguet, R. Sánchez-Delgado, M. Rossi, D. Liebowitz, F. Caruso, C. Olea-Azar, V. Moreno, A. Medeiros, M.A. Comini, L. Otero, D. Gambino, New organoruthenium complexes with bioactive thiosemicarbazones as coligands: potential anti-trypanosomal agents, Dalton Transactions 41 (2012) 1534-1543, http://dx.doi.org/10.1039/c1dt11519g.

[37] L. Blau, R.F. Menegon, G.H. Trossini, J.V. Molino, D.G. Vital, R.M. Cicarelli, G.D. Passerini, P.L. Bosquesi, C.M. Chin, Design, synthesis and biological evaluation of new aryl thiosemicarbazone as antichagasic candidates, European Journal of Medicinal Chemistry 67 (2013) 142-151, http://dx.doi.org/ 10.1016/j.ejmech.2013.04.022.

[38] I.A. Moussa, S.D. Banister, F.N. Akladios, S.W. Chua, M. Kassiou, Effects of linker elongation in a series of $N$-(2-benzofuranylmethyl)- $N^{\prime}$-(methoxyphenylalkyl) 
piperazine $\sigma 1$ receptor ligands, Bioorganic \& Medicinal Chemistry Letters 21 (2011) 5707-5710, http://dx.doi.org/10.1016/j.bmcl.2011.08.029.

[39] T.E. Pompeu, F.R. Alves, C.D. Figueiredo, C.B. Antonio, V. Herzfeldt, B.C. Moura, S.M. Rates, E.J. Barreiro, C.A.M. Fraga, F. Noël, Synthesis and pharmacological evaluation of new $N$-phenylpiperazine derivatives designed as homologues of the antipsychotic lead compound LASSBio-579, European Journal of Medicinal $\begin{array}{llll}\text { Chemistry } & 66 & \text { (2013) 122-134, http://dx.doi.org/10.1016/ }\end{array}$ j.ejmech.2013.05.027.

[40] A.C.L. Leite, R.S. de Lima, D.R.M. Moreira, M.V.O. Cardoso, A.C.G. Brito L.M.F. Santos, M.Z. Hernandes, A.C. Kiperstok, R.S. de Lima, M.B.P. Soares, Synthesis, docking, and in vitro activity of thiosemicarbazones, aminoacylthiosemicarbazides and acyl-thiazolidones against Trypanosoma cruzi, Bioorganic \& Medicinal Chemistry 14 (2006) 3749-3757, http://dx.doi.org/ 10.1016/j.bmc.2006.01.034.

[41] M.Z. Hernandes, M.M. Rabello, A.C.L. Leite, M.V. Cardoso, D.R.M. Moreira, D.J. Brondani, C.A. Simone, L.C. Reis, M.A. Souza, V.R.A. Pereira, R.S. Ferreira, J.H. McKerrow, Studies toward the structural optimization of novel thiazolylhydrazone-based potent antitrypanosomal agents, Bioorganic \& Medicinal Chemistry 18 (2010) 7826-7835, http://dx.doi.org/10.1016/ j.bmc.2010.09.056.

[42] D.R.M. Moreira, S.P. Costa, M.Z. Hernandes, M.M. Rabello, G.B.O. Filho, C.M. de Melo, L.F. da Rocha, C.A. de Simone, R.S. Ferreira, J.R. Fradico, C.S. Meira, E.T. Guimarães, R.M. Srivastava, V.R. Pereira, M.B.P. Soares, A.C.L. Leite, Structural investigation of anti-Trypanosoma cruzi 2-iminothiazolidin-4-ones allows the identification of agents with efficacy in infected mice, Journal of Medicinal Chemistry 55 (2012) 10918-10936, http://dx.doi.org/10.1021/jm301518v.

[43] D.R. Moreira, A.C.L. Leite, M.V.O. Cardoso, R.M. Srivastava, M.Z. Hernandes, M.M. Rabello, L.F. da Cruz, R.S. Ferreira, C.A. de Simone, C.S. Meira, E.T. Guimaraes, A.C. da Silva, T.A. Dos Santos, V.R.A. Pereira, M.B.P. Soares, Structural design, synthesis and structure-activity relationships of thiazolidinones with enhanced anti-Trypanosoma cruzi activity, ChemMedChem 9 (2014) 177-188, http://dx.doi.org/10.1002/cmdc.201300354.

[44] J.R. Dimmock, R.N. Puthucode, J.M. Smith, M. Hetherington, J.W. Quail, U. Pugazhenthi, T. Lechler, J.P. Stables, (Aryloxy)aryl semicarbazones and related compounds: a novel class of anticonvulsant agents possessing high activity in the maximal electroshock screen, Journal of Medicinal Chemistry 39 (1996) 3984-3997, http://dx.doi.org/10.1021/jm9603025.

[45] N. Selvakumar, M.A. Raheem, M.K. Khera, T.V. Rajale, M.S. Kumar, S. Kandepu, J. Das, R. Rajagopalan, J. Iqbal, S. Trehan, Influence of ethylene-oxy spacer group on the activity of linezolid: synthesis of potent antibacterials possessing a thiocarbonyl group, Bioorganic \& Medicinal Chemistry Letters 13 (2003) 4169-4172, http://dx.doi.org/10.1016/j.bmcl.2003.08.068.

[46] A.J. Bojarski, B. Duszyńska, M. Kołaczkowski, P. Kowalski, T. Kowalska, The impact of spacer structure on 5-HT7 and 5-HT1A receptor affinity in the group of long-chain arylpiperazine ligands, Bioorganic \& Medicinal Chemistry Letters 14 (2004) 5863-5866, http://dx.doi.org/10.1016/j.bmcl.2004.09.029.

[47] A. Kamal, S. Prabhakar, M. Janaki Ramaiah, P. Venkat Reddy, C. Ratna Reddy, A. Mallareddy, N. Shankaraiah, T.L.N. Reddy, S.N.C.V. Pushpavalli, M. PalBhadra, Synthesis and anticancer activity of chalcone-pyrrolobenzodiazepine conjugates linked via 1,2,3-triazole ring side-armed with alkane spacers, European Journal of Medicinal Chemistry 46 (2011) 3820-3831, http:/ dx.doi.org/10.1016/j.ejmech.2011.05.050.

[48] S. Yonezawa, H. Yamakawa, C. Muto, M. Hosono, T. Yamamoto, K. Hattori, M. Sakagami, H. Togame, Y. Tanaka, T. Nakano, H. Takemoto, M. Arisawa, S. Shuto, Conformational restriction approach to BACE1 inhibitors II: SAR study of the isocytosine derivatives fixed with a cis-cyclopropane ring, Bioorganic \& Medicinal Chemistry Letters 23 (2013) 2912-2915, http:// dx.doi.org/10.1016/j.bmcl.2013.03.056.

[49] S.A. Carvalho, L.O. Feitosa, M. Soares, T.E. Costa, M.G. Henriques, K. Salomão S.L. de Castro, M. Kaiser, R. Brun, J.L. Wardell, S.M. Wardell, G.H. Trossini, A.D. Andricopulo, E.F. da Silva, C.A.M. Fraga, Design and synthesis of new $(E)$ cinnamic $\mathrm{N}$-acylhydrazones as potent antitrypanosomal agents, European Journal of Medicinal Chemistry 54 (2012) 512-721, http://dx.doi.org/10.1016/ j.ejmech.2012.05.041.
[50] J.V.D. Molino, D.G. Vital, R.M.B. Cicarelli, G.D. Passerini, P.L. Bosquesi, C. ManChin, Design, synthesis and biological evaluation of new aryl thiosemicarbazone as antichagasic candidates, European Journal of Medicinal

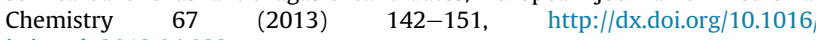
j.ejmech.2013.04.022.

[51] M. Aveniente, E.F. Pinto, L.S. Santos, B. Rossi-Bergmann, L.E. Barata, Structureactivity relationship of antileishmanials neolignan analogues, Bioorganic \& Medicinal Chemistry 15 (2007) 7337-7343, http://dx.doi.org/10.1016/ j.bmc.2007.08.016.

[52] D.N. Zhang, J.T. Li, Y.L. Song, H.M. Liu, H.Y. Li, Efficient one-pot threecomponent synthesis of $N$-(4-arylthiazol-2-yl) hydrazones in water under ultrasound irradiation, Ultrasonics Sonochemistry 19 (2012) 475-478, http:// dx.doi.org/10.1016/j.ultsonch.2011.10.017.

[53] A.M.M. Bastos, A.F.C. Alcântara, H. Beraldo, Structural analyses of 4-benzoylpyridine thiosemicarbazone using NMR techniques and theoretical calculations, Tetrahedron 61 (2005) 7045-7053, http://dx.doi.org/10.1016/ j.tet.2005.04.042.

[54] A.J. Romanha, S.L. Castro, M.N. Soeiro, J. Lannes-Vieira, I. Ribeiro, A. Talvani, B. Bourdin, B. Blum, B. Olivieri, C.L. Zani, C. Spadafora, E. Chiari, E. Chatelain, G. Chaves, J.E. Calzada, J.M. Bustamante, L.H. Freitas-Junior, L.I. Romero, M.T. Bahia, M. Lotrowska, M.B. Soares, S.G. Andrade, T. Armstrong, W. Degrave, Z.A. Andrade, In vitro and in vivo experimental models for drug screening and development for Chagas disease, Memorias do Instituto Oswaldo Cruz 105 (2010) 233-238, http://dx.doi.org/10.1590/S007402762010000200022 .

[55] R.S. Ferreira, C. Bryant, K.K. Ang, J.H. McKerrow, B.K. Shoichet, A.R. Renslo, Divergent modes of enzyme inhibition in a homologous structure-activity series, Journal of Medicinal Chemistry 52 (2009) 5005-5008, http:// dx.doi.org/10.1021/jm9009229.

[56] A.L. Matsuo, L.S. Silva, A.C. Torrecilhas, B.S. Pascoalino, T.C. Ramos, E.G. Rodrigues, S. Schenkman, A.C. Caires, L.R. Travassos, In vitro and in vivo trypanocidal effects of the cyclopalladated compound 7a, a drug candidate for treatment of Chagas' disease, Antimicrobial Agents and Chemotherapy 54 (2010) 3318-3325, http://dx.doi.org/10.1128/AAC.00323-10.

[57] J.D. Maya, S. Bollo, L.J. Nuñez-Vergara, J.A. Squella, Y. Repetto, A. Morello J. Périé, G. Chauvière, Trypanosoma cruzi: effect and mode of action of nitroimidazole and nitrofuran derivatives, Biochemical Pharmacology 65 (2003) 999-1006, http://dx.doi.org/10.1016/S0006-2952(02)01663-5.

[58] M.Z. Hernandes, S.M. Cavalcanti, D.R.M. Moreira, W.F. de Azevedo-Junior A.C.L. Leite, Halogen atoms in the modern medicinal chemistry: hints for the drug design, Current Drug Targets 11 (2010) 303-314, http://dx.doi.org/ $10.2174 / 138945010790711996$.

[59] J.M. Kraus, H.B. Tatipaka, A.S. McGuffin, N.K. Chennamaneni, M. Karimi, J. Arif, C.L. Verlinde, F.S. Buckner, M.H. Gelb, Second generation analogues of the cancer drug clinical candidate tipifarnib for anti-Chagas disease drug discovery, Journal of Medicinal Chemistry 53 (2010) 3887-3898, http:// dx.doi.org/10.1021/jm9013136.

[60] M.T. Bahia, I.M de Andrade, TA Martins, A.F do Nascimento, L.F. Diniz I.S. Caldas, A. Talvani, B.B. Trunz, E. Torreele, I. Ribeiro, Fexinidazole: a potential new drug candidate for Chagas disease, PLOS Neglected Tropical Diseases 6 (2012) e1870, http://dx.doi.org/10.1371/journal.pntd.0001870.

[61] E.F. Santiago, S.A. de Oliveira, G.B. de Oliveira Filho, D.R.M. Moreira, P.A. Gomes, A.L. da Silva, A.F. de Barros, A.C. da Silva, T.A. Dos Santos, V.R.A. Pereira, G.C. Gonçalves, F.A. Brayner, L.C. Alves, A.G. Wanderley, A.C. Leite, Evaluation of the anti-Schistosoma mansoni activity of thiosemicarbazones and thiazoles, Antimicrobial Agents and Chemotherapy 58 (2014) 352-363, http://dx.doi.org/10.1128/AAC.01900-13. Epub 2013 Oct 28

[62] B. Zingales, S.G. Andrade, M.R. Briones, D.A. Campbell, E. Chiari, O. Fernandes, F. Guhl, E. Lages-Silva, A.M. Macedo, C.R. Machado, M.A. Miles, A.J. Romanha, N.R. Sturm, M. Tibayrenc, A.G. Schijman, A new consensus for Trypanosoma cruzi intraspecific nomenclature: second revision meeting recommends TcI to TcVI, Memorias do Instituto Oswaldo Cruz 104 (2009) 1051-1054, http:// dx.doi.org/10.1590/S0074-02762009000700021. 